\title{
Effects of human land use on the terrestrial and aquatic sources of fluvial organic matter in a temperate river basin (The Meuse River, Belgium)
}

\author{
Thibault Lambert $(\mathbb{D} \cdot$ Steven Bouillon • François Darchambeau • \\ Cédric Morana · Fleur A. E. Roland · Jean-Pierre Descy • Alberto V. Borges
}

Received: 12 June 2017/ Accepted: 4 October 2017/Published online: 13 October 2017

(C) The Author(s) 2017. This article is an open access publication

\begin{abstract}
The impact of human activities on the concentrations and composition of dissolved organic matter (DOM) and particulate organic matter (POM) was investigated in the Walloon Region of the Meuse River basin (Belgium). Water samples were collected at different hydrological periods along a gradient of human disturbance (50 sampling sites ranging from 8.0 to $20,407 \mathrm{~km}^{2}$ ) and during a 1.5 year monitoring of the Meuse River at the city of Liège. This dataset was completed by the characterization of the DOM pool in groundwaters. The composition of DOM and POM was investigated through elemental ( $\mathrm{C}: \mathrm{N}$ ratios), isotopic $\left(\delta^{13} \mathrm{C}\right)$ and optical measurements including excitation emission matrix fluorescence with parallel
\end{abstract}

Responsible Editor: Jennifer Leah Tank.

Electronic supplementary material The online version of this article (doi:10.1007/s10533-017-0387-9) contains supplementary material, which is available to authorized users.

T. Lambert $(\bowtie) \cdot$ F. Darchambeau .

F. A. E. Roland · J.-P. Descy · A. V. Borges

Chemical Oceanography Unit, University of Liège, Liège,

Belgium

e-mail: thibault.lambert@unil.ch

T. Lambert

Institute of Earth Surface Dynamics, University of

Lausanne, Lausanne, Switzerland

S. Bouillon · C. Morana

Department of Earth and Environmental Sciences, KU

Leuven, Louvain, Belgium factor analysis (EEM-PARAFAC). Land use was a major driver on fluvial OM composition at the regional scale of the Meuse Basin, the composition of both fluvial DOM and POM pools showing a shift toward a more microbial/algal and less plant/soil-derived character as human disturbance increased. The comparison of DOM composition between surface and groundwaters demonstrated that this pattern can be attributed in part to the transformation of terrestrial sources by agricultural practices that promote the decomposition of soil organic matter in agricultural lands and subsequent microbial inputs in terrestrial sources. In parallel, human land had contrasting effects on the autochthonous production of DOM and POM. While the in-stream generation of fresh DOM through biological activity was promoted in urban areas, summer autochthonous POM production was not influenced by land use. Finally, soil erosion by agricultural management practices favored the transfer of terrestrial organic matter via the particulate phase. Stable isotope data suggest that the hydrological transfer of terrestrial DOM and POM in humanimpacted catchment are not subject to the same controls, and that physical exchange between these two pools of organic matter is limited.

Keywords Organic matter - Fluvial network - Urban areas · Croplands 


\section{Introduction}

Fluvial organic matter (OM) - including dissolved (DOM) and particulate (POM) forms - plays a prominent role in determining ecosystem structure and function (Tank et al. 2010) and serves as a fundamental link between the terrestrial, oceanic and atmospheric compartments of the global carbon cycle (Battin et al. 2009). The terrestrial (allochthonous) or aquatic (autochthonous) origin of OM determines its composition that in turn drives its reactivity and its impact on stream metabolism (Strauss and Lamberti 2002; Tranvik and Bertilsson 2001). Terrestrial inputs as well as autochthonous primary production of OM are the result of the interplay of several catchment attributes such as soil properties (Autio et al. 2016; Nelson et al. 1992), land cover (Giling et al. 2014; Wilson and Xenopoulos 2009), hydrology and water residence time (Lambert et al. 2014; Sanderman et al. 2009) and nutrient availability (Reche et al. 1998), all of these basic drivers being altered by human activities (Carpenter et al. 2011; Stanley et al. 2012). The conversion of natural landscapes for human use has thus been shown to alter the sources, composition and reactivity of fluvial $\mathrm{OM}$ with significant effects on carbon cycling in freshwaters (Parr et al. 2015; Petrone et al. 2011; Rosemond et al. 2015; Wilson and Xenopoulos 2009). Our ability to predict future changes in fluvial $\mathrm{OM}$ and associated ecological consequences in response to increasing anthropogenic pressures is however hampered by our limited understanding of the processes involved as well as by the fact that DOM and POM fractions are often investigated separately rather than simultaneously.

A recurrent observation emerging from studies carried out across disparate geomorphologic and hydro-climatic conditions is that streams in agricultural and urban areas have a distinctive OM composition relative to streams flowing through undisturbed catchments. More specifically, human disturbance commonly alters fluvial OM toward a more microbial/algal and less plant/soil-derived character. This pattern was first observed for DOM (Cronan et al. 1999; Giling et al. 2014; Graeber et al. 2012; Hosen et al. 2014; Masese et al. 2016; Parr et al. 2015; Williams et al. 2010, 2016; Wilson and Xenopoulos 2009; Yang et al. 2012), and recently extended to POM (Boëchat et al. 2014; Duan et al. 2014; Le Meur et al. 2017; Lu et al. 2014a, b; Ngugi et al. 2016).
Reduction of inputs of terrestrial OM due to hydrological disconnection with terrestrial sources and/or in-stream removal and greater in-stream primary production promoted by increasing light penetration and nutrient availability have been invoked as the main mechanisms interacting collectively to explain this pattern (Hosen et al. 2014; McEnroe et al. 2013; Parr et al. 2015; Wilson and Xenopoulos 2009). However, because DOM and POM are rarely investigated together, further studies are required in order to assess if human land use impacts systematically and similarly the autochthonous production of these OM pools as well as potential exchange between them.

Moreover, an alternative process that could contribute to the enrichment in the microbial character of fluvial OM could be the destabilization and transformation of terrestrial sources of $\mathrm{OM}$ by agricultural practices (Wilson and Xenopoulos 2009). Soil organic matter (SOM) - that represents the major contributor of aquatic $\mathrm{OM}$ in most freshwater ecosystems (Aitkenhead-Peterson et al. 2003) —is highly sensitive to land use changes (Butman et al. 2015). Several soil management practices such as tillage or organic fertilizer application are known to stimulate the microbial decomposition of SOM (Luo et al. 2010; McLauchlan 2006; Pisani et al. 2016). Beyond their role as decomposers, microorganisms are a ubiquitous source of OM to soils through recycling of plant and animal-derived $\mathrm{OM}$ and synthesis of new products (Dungait et al. 2012; Gleixner 2013; Miltner et al. 2012). Consequently, SOM decomposition leads to an enrichment in microbial compounds in residual SOM at the expense of plant-derived compounds (Hobara et al. 2014; Kaiser and Kalbitz 2012; Malik and Gleixner 2013). In line with this assumption is the observation that DOM in pore-water of agricultural soils can have lower molecular weights and lower aromaticity compared to soils under native vegetation (Accoe et al. 2002; Chantigny 2003; Delprat et al. 1997; Kalbitz et al. 2003). Therefore, one can hypothesize that greater SOM degradation in humandisturbed catchments results in a stronger microbial fingerprint in soil $\mathrm{OM}$ that, once exported into the fluvial network, contributes to the above mentioned shift in stream OM composition observed between disturbed and pristine catchments.

Here we report a large dataset of OM content and composition acquired between 2013 and 2015 in the Meuse River Basin, a lowland river highly impacted 
by human activities (Descy et al. 2009). Water samples were collected four times over the course of the 3 years $(01-04 / 2013,07 / 2013,02-03 / 2014$, 02-03/2015) across a gradient of land use and drainage area in 50 sub-catchments of the basin, and also during a 1.5 year monitoring of the Meuse River at the city of Liège (Belgium). Water samples were characterized for nutrients (nitrate and soluble reactive phosphorus), dissolved organic carbon (DOC), particulate organic carbon (POC) and particulate nitrogen (PN) concentrations. Isotopic $\left(\delta^{13} \mathrm{C}\right)$, elemental $(\mathrm{C}: \mathrm{N})$, and optical measurements including excitation-emission matrices and parallel factor analysis (EEMPARAFAC) were used to investigate the composition and sources of fluvial OM. In complement, groundwaters were collected throughout the Walloon Region (Belgium) and characterized for DOM composition. The objectives of this study were (1) to test the hypothesis that modification of terrestrial sources in response to human disturbance contributes to the greater microbial character of fluvial OM, (2) to investigate if terrestrial and aquatic sources of DOM and POM pools are impacted similarly by human activities, and (3) to assess the relative importance of seasonal changes relative to anthropogenic land use changes on the content and composition of fluvial OM.

\section{Materials and methods}

Study area and sampling sites

The Meuse River is a transboundary river rising in the East of France and flowing through several countries, mainly France, Belgium and The Netherlands before discharging into the North Sea (Fig. 1). The total length of the river is $885 \mathrm{~km}$ and its catchment covers about $35,000 \mathrm{~km}^{2}$. The climate of the basin is a temperate oceanic type with humid weather during all seasons, although a continental influence may cause hot dry summers and cold dry winters. The average annual rainfall is $700-1400 \mathrm{~mm}$, with the highest amount in the high Ardennes (East Belgium). The Meuse is a rain-fed river with considerable fluctuation in stream flow between years and seasons. Summer and autumn months are generally characterized by long periods of low flow $\left(<100 \mathrm{~m}^{3} \mathrm{~s}^{-1}\right.$ at the city of Liège, drainage area $=16672 \mathrm{~km}^{2}$ ) while high flows generally occur in winter and spring with stream discharge reaching $>1000 \mathrm{~m}^{3} \mathrm{~s}^{-1}$ during storm events. Due to the presence of impermeable sub-soil in the major area of the basin, rain events often result in flash floods in tributaries and the main river that last from a few days to several weeks. Long-term records of stream discharge since 1970 at three sites on the river show an increasing trend of mean annual flow over the last three decades while in parallel water temperature has increased $\sim 0.9{ }^{\circ} \mathrm{C}$ over the same period (Descy et al. 2009).

The Meuse River experiences numerous impacts from human activities since the 19th century such as hydro-morphological regulation of river channels, supply for drinking water and cooling water for industries and powerplants, and pollution from agricultural lands and domestic sewage leading to a widespread eutrophication in the basin (Bellayachi et al. 2014; Descy et al. 2009). Land use changes in the Meuse Basin have continuously occurred over the past centuries with the conversion of forests to croplands and pastures and industrial development. The past century has been marked by the intensification of agricultural practices and considerable urbanization after the late 1940's (Tu et al. 2005). Over the entire basin, land use determined by the CORINE dataset (EEA 2014) is dominated by croplands (39\%), forests $(29 \%)$, pastures (18\%) and urban areas (12\%). Agriculture has developed as intensive farming with the use of large quantities of chemical fertilizers and pesticides since the 1960's (Burny and Debode 2013). Tillage, liming and application of chemical and/or organic fertilizers are common agricultural practices in the Walloon region, however they vary widely between each agricultural areas as well as the plot scale (Genot et al. 2009). Organic farming, an agricultural model more respectful of the environment, represents about $7 \%$ of the Walloon agricultural areas (Burny and Debode 2013). Human activities, especially agricultural practices, have profoundly affected soil structure and soil resistance to erosion and consequently their ability to provide ecosystem services (Bellayachi et al. 2014). Approximatively $90 \%$ of agricultural land shows a deficiency in soil organic carbon (SOC) with a level of SOC below $1.5 \%$ in the ploughed layer while the majority of grasslands and forested areas have values 3-5 times higher (Bellayachi et al. 2014). Moreover, soil erosion and transport of eroded particles to watercourses by rainfall and water runoff are enhanced in agricultural 
Fig. 1 Land use in the Walloon Region of the Meuse River basin and distribution of sampling sites

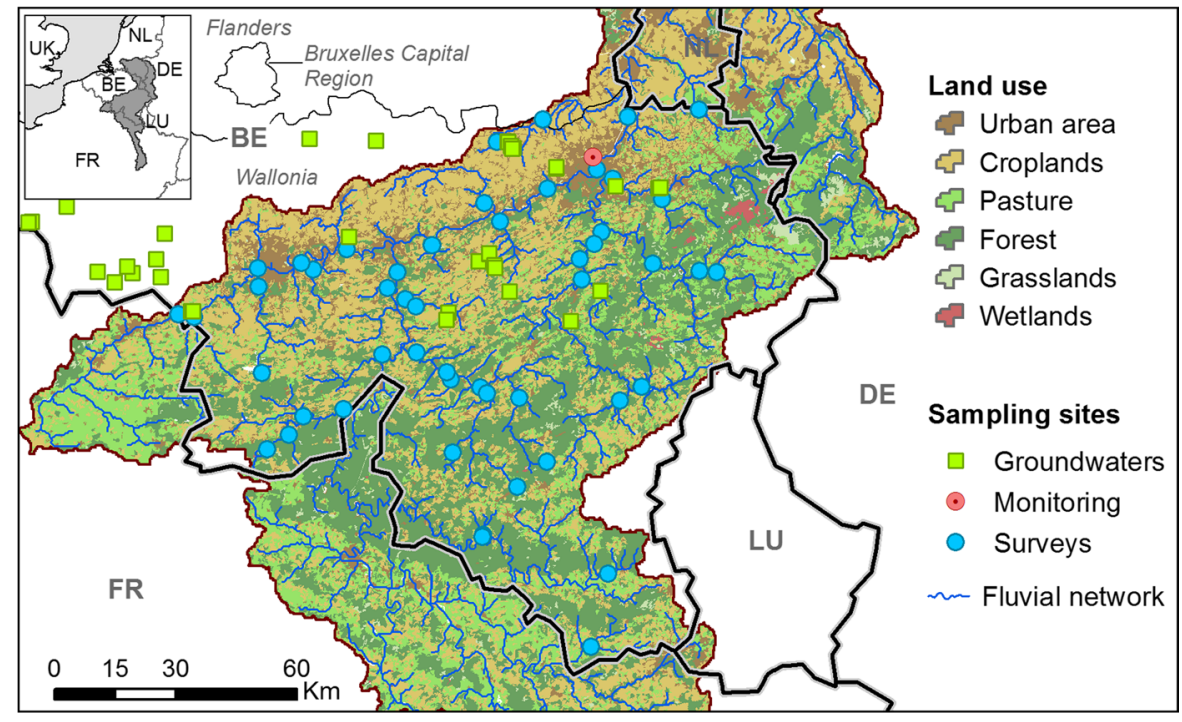

areas because of the vulnerability of their soil and the prevalence of row crops. Due to abundant precipitation, irrigation is rarely used in the field. Nowadays, about $96 \%$ of the wastewater from urban agglomerations in Wallonia is collected, while $84 \%$ is effectively treated in wastewater treatment plants, meaning that only $20 \%$ of domestic wastewater is delivered untreated directly into streams and rivers. Collection and treatment of wastewater in large agglomerations ( $>10,000$ inhabitants) are compliant in line with European requirements, with only $5 \%$ of wastewater non collected or collected but no treated. The situation is quite different for low agglomerations $(<2000$ inhabitants) where $60 \%$ of wastewater is not treated.

Spatial surveys were carried out in the Walloon Region (Belgium) of the Meuse River that accounts for $\sim 37 \%$ of the total basin area (Fig. 1). Sampling sites $(\mathrm{n}=50)$ ranged in catchment size from 8.0 to $20,407 \mathrm{~km}^{2}$, in Strahler order from 1 to 6 , in elevation from 138 to $552 \mathrm{~m}$ and in slope from $0.7^{\circ}$ to $4.2^{\circ}$. Across catchments, croplands ranged from 0 to $81.5 \%$ (average $33.1 \%$ ), urban areas from 0.7 to $26.1 \%$ (average $8.9 \%$ ), pastures from 0 to $50.3 \%$ (average $18.5 \%$ ) and forest areas from 0.3 to $95.8 \%$ (average $37.6 \%$ ). The other land classes (grasslands and wetlands) represented less than $1.5 \%$ on average. Urban areas and croplands are spatially auto-correlated in the Walloon Region (Pearson $r=0.40$ ) and both land uses are inversely correlated with forested areas (Pearson $r=-0.68$ and Pearson $r=-0.74$, respectively). Pasture cover is inversely correlated with croplands (Pearson $r=-0.43$ ), but is unrelated statistically to urban and forested areas.

Field data collection

Spatial surveys took place between 8 January and 15 April 2013 (S1), 12-31 July 2013 (S2), 18 February27 March 2014 (S3), and 3 February-12 March 2015 (S4) (Table 1). Monitoring of the Meuse River was carried out at the city of Liège between the 23/01/2013 and the 03/07/2014 at a bi-monthly frequency minimum $(\mathrm{n}=49)$. At this point, land use is dominated by forest areas $(39.5 \%)$, croplands $(32.5 \%)$, pasture $(21.8 \%)$ and urban areas $(8.5 \%)$. Groundwaters $(\mathrm{n}=42)$ were collected throughout the Walloon Region (Fig. 1). At most sites, stream water was collected from a bridge or directly from the shore as far as possible away from the river bank. Approximatively $2 \mathrm{~L}$ of water were collected $0.5 \mathrm{~m}$ below the water surface, and filtration and preservation were performed on the same day on return at the laboratory. Water temperature was measured in situ with portable field probes calibrated using standard protocols (YSI ProPlus probe). Collecting depth for groundwaters ranged from 2 to $25 \mathrm{~m}$ under soil surface. Groundwaters samples were analyzed for DOM absorption and fluorescent properties only.

Samples for total suspended matter (TSM), POC, $\mathrm{PN}$ and isotope composition of POC $\left(\delta^{13} \mathrm{C}_{\mathrm{POC}}\right)$ were obtained by filtering $50-900 \mathrm{~mL}$ of water on precombusted $\left(4 \mathrm{~h}\right.$ at $\left.500{ }^{\circ} \mathrm{C}\right)$ glass fiber filters $(25 \mathrm{~mm}$ 
Table 1 Period of sampling, cumulated rainfall over the sampling period (calculated near the city of Liège), specific discharge and selected attributes (mean \pm standard deviation, minimum-maximum) of water quality at sampling sites during the field campaigns, including water temperature (Water T), Chlorophyll a (Chl- $a$ ), soluble reactive phosphorus (SRP) and $\mathrm{NO}_{3}{ }^{-}$concentrations

\begin{tabular}{|c|c|c|c|c|}
\hline Survey & $\mathrm{S} 1$ & $\mathrm{~S} 2$ & $\mathrm{~S} 3$ & $\mathrm{~S} 4$ \\
\hline Period & $\begin{array}{l}8 \text { January-15 April } \\
2013\end{array}$ & 12 July-31 July 2013 & $\begin{array}{l}18 \text { February-27 March } \\
2014\end{array}$ & $\begin{array}{l}3 \text { February-12 March } \\
2015\end{array}$ \\
\hline Cumulated rainfall $(\mathrm{mm})^{\mathrm{a}}$ & 114,4 & 13,8 & 24,5 & 49,5 \\
\hline $\begin{array}{l}\text { Specific discharge }\left(\mathrm{m}^{3} \mathrm{~s}^{-1}\right. \\
\left.\mathrm{km}^{-2}\right)^{\mathrm{a}}\end{array}$ & $\begin{array}{l}0.022 \pm 0.015 \\
\quad(0.003-0.077)\end{array}$ & $\begin{array}{l}0.004 \pm 0.002 \\
\quad(0.001-0.015)\end{array}$ & $\begin{array}{l}0.009 \pm 0.004 \\
\quad(0.001-0.022)\end{array}$ & $\begin{array}{l}0.019 \pm 0.009 \\
\quad(0.003-0.038)\end{array}$ \\
\hline Water $\mathrm{T}\left({ }^{\circ} \mathrm{C}\right)$ & $5.8 \pm 2.0(2.1-10.8)$ & $\begin{array}{c}18.1 \pm 3.1 \\
(13.3-25.9)\end{array}$ & $8.0 \pm 1.1(5.9-9.9)$ & $5.6 \pm 1.1(3.2-7.5)$ \\
\hline $\operatorname{TSM}\left(\mathrm{mg} \mathrm{L}^{-1}\right)$ & $\begin{array}{l}19.2 \pm 26.8 \\
\quad(0.5-145.5)\end{array}$ & $6.7 \pm 4.3(1.8-20.8)$ & $7.6 \pm 11.2(0.2-64.5)$ & $\begin{array}{l}20.4 \pm 29.7 \\
\quad(0.2-111.2)\end{array}$ \\
\hline Chl- $a\left(\mu \mathrm{g} \mathrm{L}^{-1}\right)$ & $0.8 \pm 1.5(0.04-10.2)$ & $0.7 \pm 0.8(0.07-5.2)$ & $1.3 \pm 1.4(0.09-8.6)$ & $0.9 \pm 0.8(0.1-4.1)$ \\
\hline $\operatorname{SRP}\left(\mu \mathrm{g} \mathrm{L}^{-1}\right)$ & $\begin{array}{l}46.5 \pm 46.5 \\
\quad(1.9-204.6)\end{array}$ & $\begin{array}{l}65.1 \pm 80.6 \\
\quad(6.2-542.5)\end{array}$ & $\begin{array}{l}43.4 \pm 46.5 \\
\quad(1.9-213.9)\end{array}$ & $40.3 \pm 46.5(0-204.6)$ \\
\hline $\mathrm{NO}_{3}\left(\mathrm{mg} \mathrm{L}^{-1}\right)$ & $\begin{array}{l}16.6 \pm 6.7 \\
\quad(3.6-30.69)\end{array}$ & $13.3 \pm 5.7(2.1-27.7)$ & $16.0 \pm 6.5(3.1-29.3)$ & $15.7 \pm 6.6(2.0-29.0)$ \\
\hline
\end{tabular}

${ }^{\mathrm{a}}$ Data used for specific discharge and cumulated rainfall calculation are available at http://voies-hydrauliques.wallonie.be/opencms/ opencms/fr/hydro/Archive/

$\mathrm{GF} / \mathrm{F}, 0.7 \mu \mathrm{m}$ nominal pore size). The filtrate was further filtered on $0.2 \mu \mathrm{m}$ polyethersulfone syringe filters for DOC and $\delta^{13} \mathrm{C}_{\mathrm{DOC}}$ analysis (stored in $40 \mathrm{ml}$ glass vials with Polytetrafluoroethylene coated septa with $\left.50 \mu \mathrm{H}_{3} \mathrm{PO}_{4}\right)$ and colored DOM (CDOM) and fluorescent DOM (FDOM) analysis (stored in $20 \mathrm{ml}$ amber glass vials with PTFE-coated septa without $\mathrm{H}_{3} \mathrm{PO}_{4}$ additions). Samples for nitrates $\left(\mathrm{NO}_{3}{ }^{-}\right)$and soluble reactive phosphorus (SRP) concentrations were filtered on a $0.2 \mu \mathrm{m}$ PES syringe filter, collected in $50 \mathrm{~mL}$ plastic vials, to which $200 \mu \mathrm{L}$ of $\mathrm{H}_{2} \mathrm{SO}_{4} 5 \mathrm{~N}$ was added.

Filters for POC, $\mathrm{PN}$ and $\delta^{13} \mathrm{C}_{\mathrm{POC}}$ were decarbonated with $\mathrm{HCl}$ flumes for $4 \mathrm{~h}$, re-dried and packed in silver cups prior to analysis on a EA-IRMS (Thermo FlashHT with Thermo DeltaV Advantage). Calibration of POC, $\mathrm{PN}$ and $\delta^{13} \mathrm{C}_{\mathrm{POC}}$ measurements was performed with acetanilide $\left(\delta^{13} \mathrm{C}=-27.65 \pm 0.05 \%\right)$ and leucine $\left(\delta^{13} \mathrm{C}=-13.47 \pm 0.07 \%\right.$ ) as standards. All standards were internally calibrated against the international standard IAEA-C6 and IAEA-N1. Reproducibility of $\delta^{13} \mathrm{C}_{\mathrm{POC}}$ measurements was typically better than $\pm 0.2 \%$ and relative standard deviation for POC and PN measurements were always below 5\%. The C:N ratio was calculated as a molar ratio, and \% $\mathrm{POC}$ as the ratio of POC concentrations divided by TSM concentrations. Analysis for DOC concentrations and $\delta^{13} \mathrm{C}_{\mathrm{DOC}}$ were performed with an Aurora1030 total organic carbon analyzer (OI Analytical) coupled to a Delta V Advantage isotope ratio mass spectrometer. Typical precision observed in duplicate samples was in $>95 \%$ cases $< \pm 5 \%$ for DOC and $\pm 0.2 \%$ for $\delta^{13} C_{\text {DOC }}$. Quantification and calibration were performed with series of standards prepared in different concentrations, using both IAEA-C6 $\left(\delta^{13} \mathrm{C}=-10.4 \%\right.$ ) and in-house sucrose standards $\left(\delta^{13} \mathrm{C}=-26.9 \%\right.$ o). All data are reported in the $\delta$ notation relative to VPDB (Vienna Pee Dee Belemnite).

$\mathrm{NO}_{3}{ }^{-}$concentrations were measured by spectrophotometry using the sulphanilamide colorimetric method (APHA 1998). The detection limit of this method is $0.01 \mathrm{mg} \mathrm{L}^{-1}$. SRP was determined by spectrophotometry using the ammonium molybdatepotassium antimonyl tartrate method (APHA 1998). Chlorophyll-a (Chl- $a$ ) concentration was analysed by high performance liquid chromatography (HPLC) after acetone extraction (90\%) of the material filtered on Macherey-Nagel $47 \mathrm{~mm}$ diameter GF-5 filters, according to Descy et al. (2005), using a Waters HPLC system equipped with a Waters 996 PDA detector and a Water 470 fluorescence detector.

Absorbance was recorded on a Perkin-Elmer UV/ Vis $650 \mathrm{~S}$ spectrophotometer using a $1 \mathrm{~cm}$ quartz 
cuvette. Absorbance spectra were measured between 200 and $700 \mathrm{~nm}$ at $1 \mathrm{~nm}$ increment and instrument noise was assessed measuring ultrapure (Type 1) Milli-Q (Millipore) water as blank. After subtracting the blank spectrum, the correction for scattering and index of refraction was performed by fitting the absorbance spectra to the data over the $200-700 \mathrm{~nm}$ range according to the following equation:

$\mathrm{A}_{\lambda}=\mathrm{A}_{0} \mathrm{e}^{-\mathrm{S}\left(\lambda-\lambda_{0}\right)}+\mathrm{K}$,

where $A_{\lambda}$ and $A_{0}$ are the absorbance measured at defined wavelength $\lambda$ and at reference wavelength $\lambda_{0}=375 \mathrm{~nm}$, respectively, $S$ the spectral slope $\left(\mathrm{nm}^{-1}\right)$ that describes the approximate exponential decline in absorption with increasing wavelength and $\mathrm{K}$ a background offset. The fit was not used for any purpose other than to provide an offset value $\mathrm{K}$ that was then subtracted from the whole spectrum. Napierian absorption coefficients were then calculated according to:

$\mathrm{a}_{\lambda}=2.303 \times \mathrm{A}_{\lambda} / \mathrm{L}$,

where $a_{\lambda}$ is the absorption coefficient $\left(\mathrm{m}^{-1}\right)$ at wavelength $\lambda, \mathrm{A}_{\lambda}$ the absorbance corrected at wavelength $\lambda$ and $L$ the path length of the optical cell in $\mathrm{m}$ $(0.01 \mathrm{~m})$. Fluorescence intensity was recorded on a Perkin-Elmer LS45 fluorescence spectrometer using a $1 \mathrm{~cm}$ quartz cuvette across excitation wavelengths of $220-450 \mathrm{~nm}$ (5 nm increments) and emission wavelengths of $230-600 \mathrm{~nm}(0.5 \mathrm{~nm}$ increments) in order to build EEMs. If necessary, samples were diluted until $\mathrm{A}_{254}<0.2 \mathrm{~m}^{-1}$ to avoid problematic inner filter effects (Ohno 2002). Before each measurement session (i.e., each day), a Milli-Q water sample was also measured and subtracted from EEMs.

Characterization of DOM composition from UVVis and fluorescence analysis

The $\mathrm{a}_{250}: \mathrm{a}_{365}$ ratio (also called E2:E3 ratio) was calculated from CDOM absorption as the absorption measured at $\lambda=250 \mathrm{~nm}$ divided by the absorption measured at $\lambda=365 \mathrm{~nm}$. The $\mathrm{a}_{250}: \mathrm{a}_{365}$ ratio has been related to the aromatic content and molecular size of DOM with increasing values indicating a decrease in aromaticity and molecular size (Peuravuori and Pihlaja 1997). Fluorescence intensities measured at specific excitation wavelengths were used to derive several proxy of DOM composition. The fluorescence index (FI) was calculated as the ratio of the emission intensities at 470 and $520 \mathrm{~nm}$ at an excitation wavelength of $370 \mathrm{~nm}$ (McKnight et al. 2001). FI is inversely related to the lignin content and to the aromaticity of DOM and is indicative of the contribution of microbially derived compounds to the DOM pool. FI values typically range from 1.3 to 2.0 , i.e., from terrestrial, higher-plant DOM sources to predominant microbial DOM sources. The $\beta: \alpha$ ratio was calculated as the ratio of the emission intensity measured at $380 \mathrm{~nm}$ ( $\beta$ region) divided by the emission intensity maximum recorded between 420 and $435 \mathrm{~nm}$ ( $\alpha$ region) at an excitation wavelength of $310 \mathrm{~nm}$ (Parlanti et al. 2000). The $\beta: \alpha$ ratio-typically ranging from 0.4 to $>1.0$ - is an indicator of recently microbially produced DOM, with higher values representing a higher proportion of fresh DOM.

\section{PARAFAC modeling}

EEMs preprocessing (including removing first and second Raman scattering, standardization to Raman units, absorbance corrections and inner filter effects) was performed prior the PARAFAC modeling. The scans were standardized to Raman units (normalized to the integral of the Raman signal between 390 and $410 \mathrm{~nm}$ in emission at a fixed excitation of $350 \mathrm{~nm}$ ) with a Milli-Q water sample run the same day as the samples (Zepp et al. 2004). PARAFAC model was build using MATLAB (MathWorks, Natick, MA, USA) and the drEEM Toolbox version 1.0 (Murphy et al. 2013). Validation of the model was performed by split-half analysis and random initialization. The normalization step was applied to scale each EEM to its total signal, thus ensuring the model focused entirely on compositional rather than concentration gradients. The positions of maximums peaks of the seven PARAFAC components determined to adequately model the dataset were compared to the classical nomenclature and to other reported PARAFAC models built in agro-urban catchments in an attempt to provide a general description from previous studies (Table 2; Supplementary Fig. 1). The maximum fluorescence $\left(F_{\text {Max }}\right)$ values of each component for a particular sample provided by the model were summed to calculate the total fluorescence signal $\left(F_{\mathrm{Tot}}\right)$ of the sample in Raman unit (R.U.). The relative 
Table 2 Spectral properties (excitation and emission maxima $\left(\mathrm{Ex}_{\max } / \mathrm{Em}_{\max }\right)$ of the seven components identified using PARAFAC modelling, comparison with previously identified

\begin{tabular}{lllll}
\hline Comp. & $\begin{array}{l}\mathrm{Ex}_{\max } \\
(\mathrm{nm})\end{array}$ & $\begin{array}{l}\mathrm{Em}_{\max } \\
(\mathrm{nm})\end{array}$ & $\begin{array}{l}\text { Comparison with others PARAFAC } \\
\text { models built in argro-urban } \\
\text { catchments }\end{array}$ & Description \\
& & &
\end{tabular}

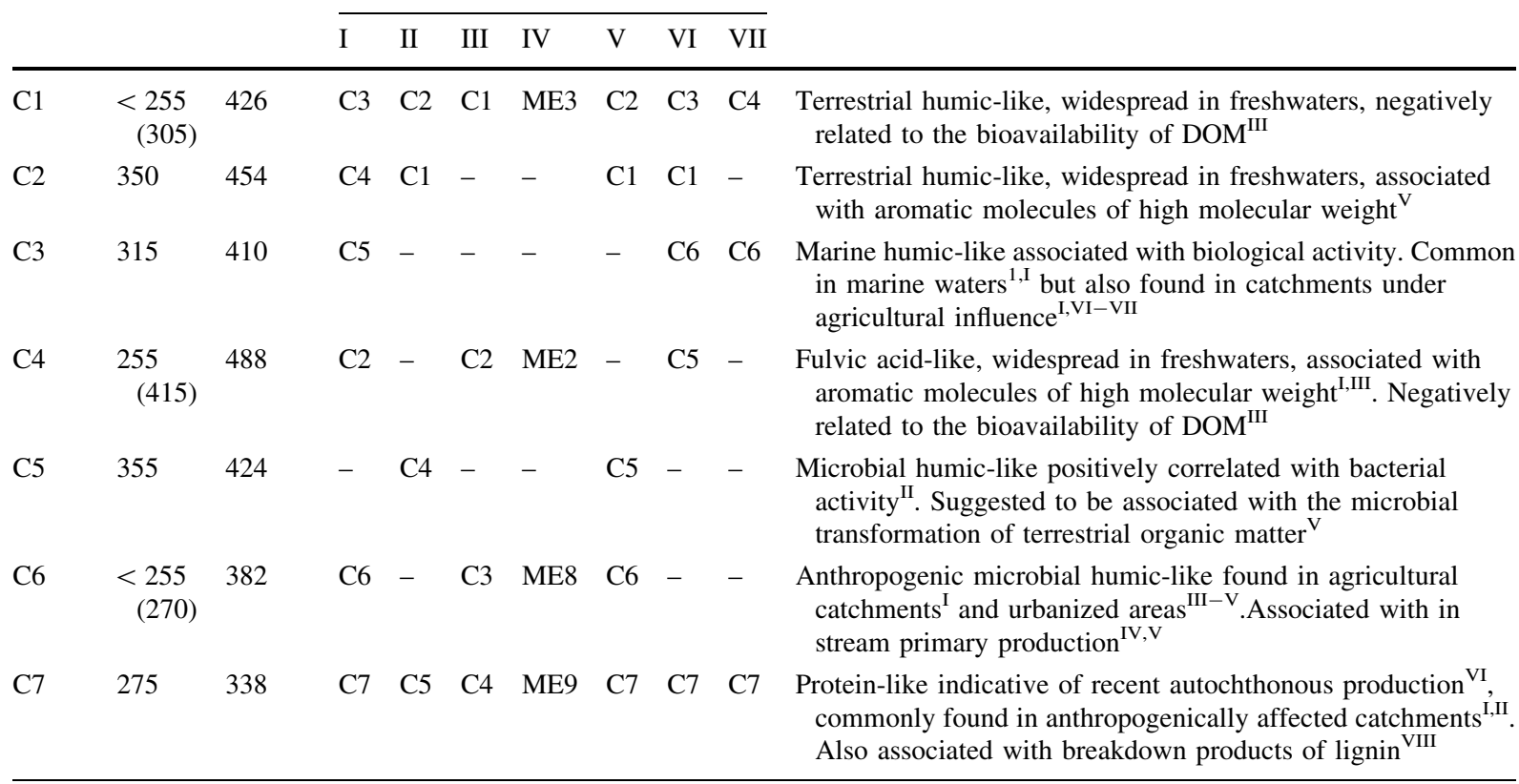

I: Stedmon and Markager (2005); II: Williams et al. (2010); III: Hosen et al. (2014); IV: Parr et al. (2015); V: Williams et al. (2013), (2016); VI: Yamashita et al. (2010); VII: Graeber et al. (2012); VIII: Hernes et al. (2009)

abundance of any particular PARAFAC component $\mathrm{X}$ was then calculated as $\% \mathrm{C}_{\mathrm{X}}=F_{\mathrm{Max}}(\mathrm{X}) / F_{\mathrm{Tot}}$.

\section{Statistical analysis}

A principal component analysis (PCA) was performed to investigate the role of human land use on stream $\mathrm{OM}$ concentration and composition. The concentrations of DOC and POC, C:N ratios, optical properties of DOM including level of CDOM $\left(\mathrm{a}_{350}\right)$, total fluorescence $\left(F_{\text {tot }}\right)$, bulk composition $\left(\mathrm{a}_{250}: \mathrm{a}_{365}, \beta: \alpha\right.$ and FI ratios) and the relative abundance of PARAFAC components were used as the variables. Given the different units of these variables, data were scaled to zero-mean and unit-variance as recommended (Borcard et al. 2011). The PCA was performed using the prcomp function in R software. Mann-Whitney $\mathrm{t}$ tests were performed to investigate spatial and temporal differences in fluvial OM content and composition. A redundancy analysis (RDA) was performed components in other human-impacted catchments and general description based on the literature 


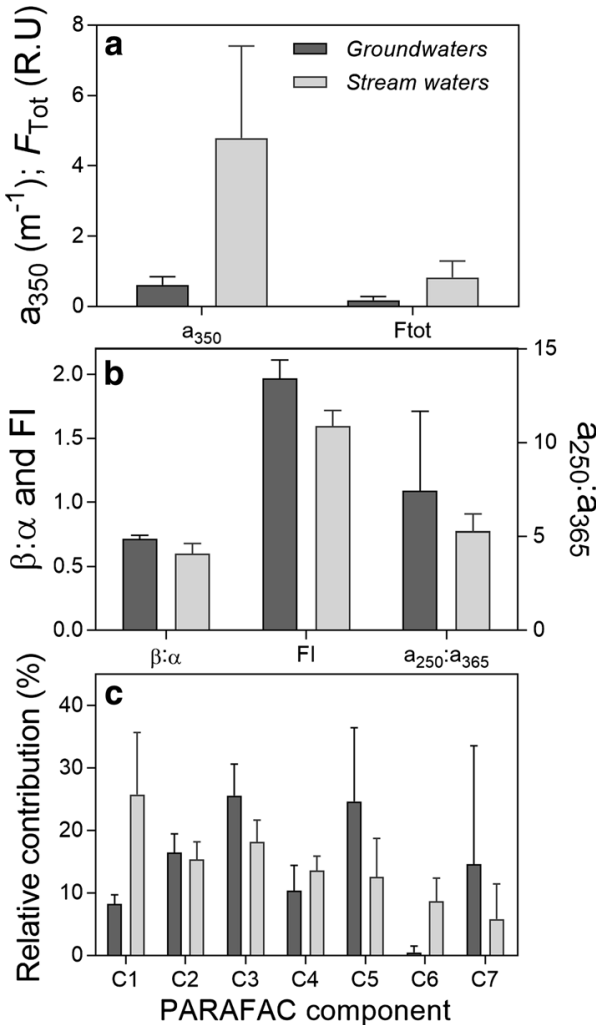

Fig. 2 Comparison of the a level of colored DOM $\left(\mathrm{a}_{350}\right)$ and fluorescent DOM $\left(F_{\text {Tot }}\right)$, b $\beta: \alpha, F I$, and $\mathrm{a}_{250}: \mathrm{a}_{365}$ ratios, and c relative contribution of PARAFAC components in surface and groundwaters. Values for surface waters were calculated based on samples collected during field surveys

\section{Results}

General context of field surveys

Field surveys S1, S3 and S4 were carried out at the winter-spring transition during three consecutive years. Cumulative rainfall was highest during $\mathrm{S} 1$ and $\mathrm{S} 4$ relative to $\mathrm{S} 3$, leading to higher mean specific discharges, while water temperatures were higher during $\mathrm{S} 3$ relative to $\mathrm{S} 1$ and $\mathrm{S} 4$ due to mild climatic conditions in 2014 (Table 1). The survey S2 occurred in summer and was characterized by lowest specific discharge and highest water temperatures. Minimum and maximum Chl- $a$ concentrations over the study period were 0.04 and $10.2 \mu \mathrm{g} \mathrm{L}^{-1}$, respectively, with highest mean concentration recorded during S3, and displayed no patterns with land use $(p>0.05$ for all periods and with all land use categories). Overall, $\mathrm{NO}_{3}{ }^{-}$and SRP concentrations were elevated in the
Meuse River Basin, ranging from $2.0-30.7 \mathrm{mg} \mathrm{L}^{-1}$ and 1.9-542.5 $\mu \mathrm{g} \mathrm{L}^{-1}$, respectively. $\mathrm{NO}_{3}{ }^{-}$and SRP concentrations were respectively lower and higher during summer compared to the other periods.

Stream $\mathrm{OM}$ in the Meuse Basin during surveys

POC concentrations ranged from 0.3 to $6.8 \mathrm{mg} \mathrm{L}^{-1}$ (Table 3). Stream waters exhibited slightly higher concentrations along with higher $\mathrm{C}: \mathrm{N}$ ratios during $\mathrm{S} 1$ and $\mathrm{S} 4$ compared to $\mathrm{S} 2$ and $\mathrm{S} 3$. Mean $\delta^{13} \mathrm{C}_{\mathrm{POC}}$ values were similar between $\mathrm{S} 1$ and $\mathrm{S} 4$, while significant lowest and highest signatures were recorded during S2 and S3, respectively. Stream DOC concentrations ranged from 0.2 to $6.6 \mathrm{mg} \mathrm{L}^{-1}$, with higher mean DOC concentrations in summer, similar concentrations between $\mathrm{S} 1$ and $\mathrm{S} 3$, and lowest concentrations during S4. Mean total DOM fluorescence $\left(F_{\text {tot }}\right)$ and CDOM level $\left(\mathrm{a}_{350}\right)$ were higher during S2 and S4 compared to S1 and S3. The DOC:POC ratio was $>1$ for most sampling sites except during the survey $\mathrm{S} 4$ during which $\sim 38 \%$ of streams had DOC:POC ratio $<1$ (against $\sim 7 \%$ for the surveys $\mathrm{S} 1-\mathrm{S} 3$ ). Mean $\delta^{13} \mathrm{C}_{\mathrm{DOC}}$ values were lowest during $\mathrm{S} 1$ and similar between S2, S3 and S4. DOM composition investigated through optical proxies revealed that stream DOM during S1 was more aromatic and had a higher average molecular weight (lower $\mathrm{a}_{250}: \mathrm{a}_{365}$ ratio) compared to the other surveys that were characterized by a higher contribution of microbial compounds (higher FI) and recently produced DOM (higher $\beta: \alpha$ ) compared to $\mathrm{S} 1$. Changes in DOM composition between surveys were also supported by PARAFAC results, with higher relative contribution of terrestrial humic-like components $\mathrm{C} 1, \mathrm{C} 2$ and $\mathrm{C} 4$ during S1 compared to the other periods. The most significant change in terms of DOM fluorescence for the surveys S2-S4 compared to S1 was the net increase in \% $\%$ and \% 7 that were more pronounced than the increase in \%C3 and \%C5. It should be noted that increases in the relative contributions of microbial humic-like and protein-like components during surveys $\mathrm{S} 2-\mathrm{S} 4$ were not simply due to a decrease in the fluorescence of terrestrial humic-like components. Indeed, $\% \mathrm{C} 1, \% \mathrm{C} 2$ and $\% \mathrm{C} 4$ were highest during $\mathrm{S} 1$ but their highest $F_{\text {Max }}$ values were recorded during S2 for $\mathrm{C} 1$ and $\mathrm{C} 2$ and during $\mathrm{S} 4$ for $\mathrm{C} 4$. Increasing relative contribution of non-terrestrial fluorophores 


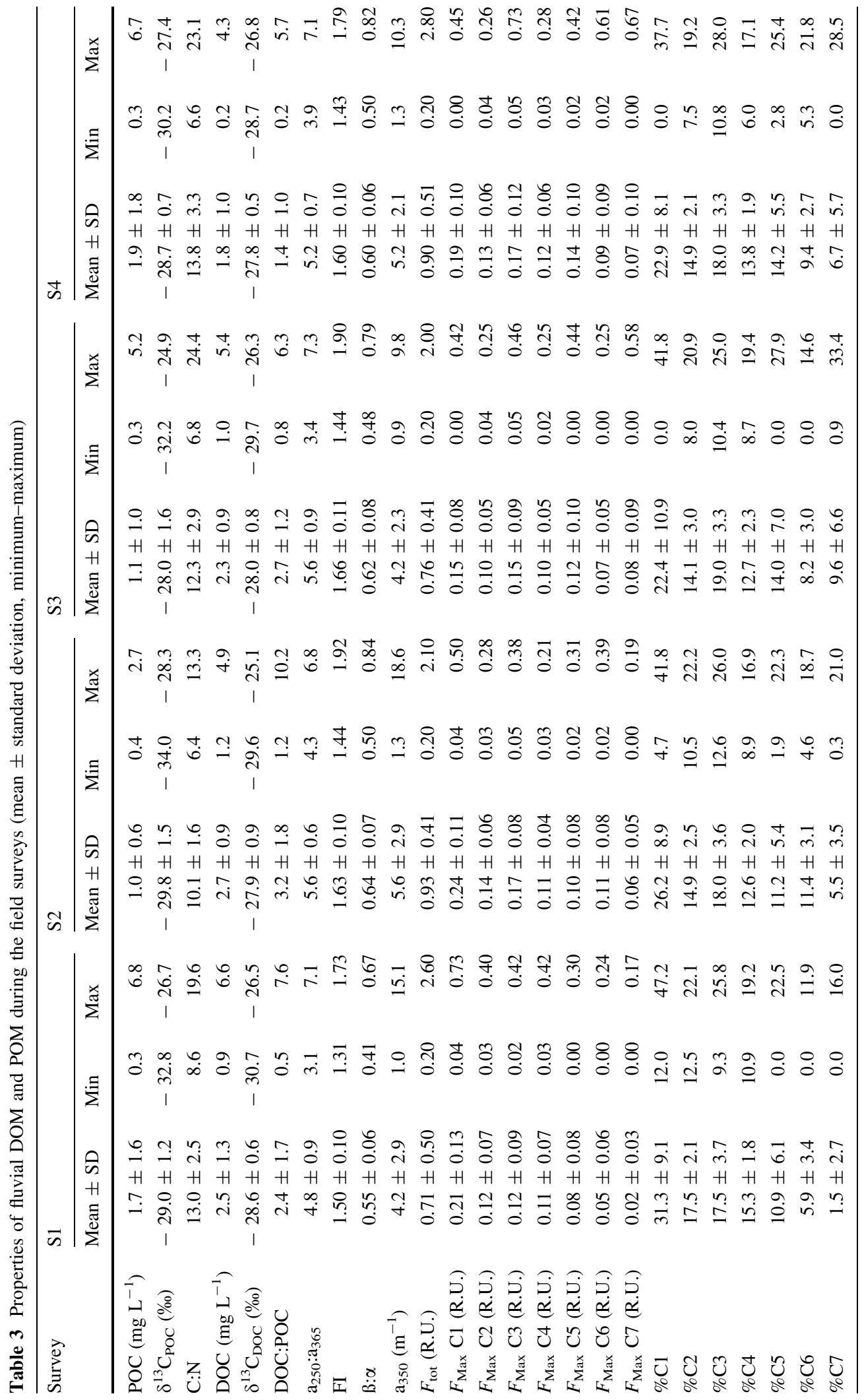


was thus rather due to an increase in the concentrations of microbial humic-like and protein-like fluorophores.

Groundwaters versus surface waters

Groundwaters samples $(\mathrm{n}=40)$ contained a lower amount of colored DOM $\left(\mathrm{a}_{350}=0.61 \pm 0.2 \mathrm{~m}^{-1}\right)$ and fluorescent DOM $\left(F_{\text {tot }}=0.18 \pm 0.11\right.$ R.U. $)$ compared to surface waters (Fig. 2a). Groundwater DOM differed markedly in composition compared to surface waters, showing higher FI $(1.97 \pm 0.15), \beta: \alpha$ $(0.72 \pm 0.03)$ and $\mathrm{a}_{250}: \mathrm{a}_{365}(7.43 \pm 1.23)$ ratios (Fig. 2b), lower contribution of terrestrial humic-like components $\mathrm{C} 1$ and $\mathrm{C} 4$ and higher proportions of microbial- (C3 and C5) and protein- (C7) like components (Fig. 2c). \%C2 was similar between ground and surface waters, and finally C6 was not found in groundwaters $(\% \mathrm{C} 6<1)$.

Effects of human land use on stream water quality and stream $\mathrm{OM}$

SRP showed a stronger correlation with urban areas than croplands while $\mathrm{NO}_{3}{ }^{-}$better correlated with croplands than urban areas (Table 4). Almost all the attributes of stream OM were influenced by land use. Keeping in mind that urban and cropland areas are spatially auto-correlated in the Meuse basin, these two land use categories were found to have strong and similar effects. Increasing urbanization and croplands extent resulted in higher POM (POC) concentrations of lower $\mathrm{C}: \mathrm{N}$ ratios, lower DOC:POC ratio, and more microbial DOM (higher \%C3, \%C5 and \%C6) in stream waters. Stream DOM concentrations (DOC) and aromaticity $\left(\mathrm{a}_{250}: \mathrm{a}_{365}\right.$ ratio) correlated only with urban areas and not with croplands. Furthermore, \%C6 correlated stronger with urban areas than croplands while C:N and DOC:POC ratio correlated better with croplands than with urban areas. Results of the PCA (Fig. 3) clearly demonstrated that the combined effects of urbanization and agriculture (PC1, 41.4\% of the total variance) alter fluvial OM toward a more microbial/algal (\%C3, \%C5, \%C6, \%C7, $\mathrm{a}_{250}: \mathrm{a}_{365}$, FI, $\beta: \alpha$, positive loadings) and less plant/soil-derived character (C:N, \%C1, \% 2 , \% 4 , negative loadings). Forest areas-inversely related to the relative occupation of urban and cropland areas at the catchment level-exhibited opposite effects on water quality and stream OM while weak or no significant correlations were found between grasslands and stream water chemistry. Seston Chl- $a$ concentrations were the only variable of stream water found not to be related to any land use category, and \%C7 was only negatively related to forest areas. Overall, the above-mentioned relationships between stream water and land use were consistent across surveys (Supplementary Table 1).

Monitoring of the Meuse River at the city of Liège

Stream water discharge ranged from $<10$ to $1167 \mathrm{~m}^{3} \mathrm{~s}^{-1}$ over the study period, with a typical hydrograph showing high base flow level and peak discharge during storm events during autumn/winter followed by a gradual decrease towards low flow conditions and lower peak discharge in summer (Fig. 4a). Water temperature fluctuated between 3.5 and $24.3{ }^{\circ} \mathrm{C}$ with a marked seasonal cycle characterized by a gradual increase in temperature from winter to summer (maximum in August) followed by decreasing temperature towards lowest values in January and February. TSM concentrations (from 1.7 to $41.1 \mathrm{mg} \mathrm{L}^{-1}$ ) increased markedly with increasing stream discharge to the contrary of SRP concentrations (from 31.0 to $344.1 \mu \mathrm{g} \mathrm{L}^{-1}$ ) that increased gradually during summer periods as stream discharge reached its lower level Fig. 4b). $\mathrm{NO}_{3}{ }^{-}$(from 11.2 to $18.0 \mathrm{mg} \mathrm{L}^{-1}$ ) concentrations showed a more complex pattern unrelated to stream fluctuation but trended to be higher during winter.

Fluvial POM dynamic was strongly related to stream discharge fluctuations, both in terms of concentrations and composition (Fig. 5a, b). Thus, POC concentrations (from 0.7 to $3.2 \mathrm{mg} \mathrm{L}^{-1}$ ), $\delta^{13-}$ $\mathrm{C}_{\mathrm{POC}}$ values (from -29.3 to $-20.6 \%$ ), and $\mathrm{C}: \mathrm{N}$ ratios (from 8.0 to 17.8) increased with increasing discharge while \%POC decreased. Regarding fluvial DOM, DOC concentrations (from 1.9 to $5.3 \mathrm{mg} \mathrm{L}^{-1}$ ) were not correlated with stream discharge (Fig. 6a). $\delta^{13} \mathrm{C}_{\text {DOC }}$ (from - 29.8 to $-26.7 \%$ ) did not showed any clear seasonal variation or relationship with discharge while optical derived proxies for DOM composition, namely the $\beta: \alpha$, FI and $\mathrm{a}_{250}: \mathrm{a}_{365}$ ratios, all showed marked seasonal fluctuations and negative relationships with discharge. $\beta: \alpha$ and FI ratio typically ranged from 0.52 to 0.64 and from 1.55 to 1.66 during high flow periods, respectively, and increased from 0.59 to 0.66 and from 1.62 to 1.70 during low flow summer months, respectively. $\mathrm{a}_{250}: \mathrm{a}_{365}$ ratio ranged 
Table 4 Correlations between water quality and fluvial OM properties and land use

\begin{tabular}{|c|c|c|c|c|c|c|c|c|}
\hline & \multicolumn{2}{|c|}{ Urban areas $(\%)$} & \multicolumn{2}{|c|}{ Croplands (\%) } & \multicolumn{2}{|c|}{ Forest areas $(\%)$} & \multicolumn{2}{|c|}{ Pastures (\%) } \\
\hline & Pearson $r$ & $\mathrm{p}$ value & Pearson $r$ & $\mathrm{p}$ value & Pearson $r$ & $\mathrm{p}$ value & Pearson $r$ & $\mathrm{p}$ value \\
\hline Chl- $a\left(\mu \mathrm{g} \mathrm{L}^{-1}\right)$ & 0.02 & NS & -0.05 & NS & -0.17 & NS & 0.07 & NS \\
\hline $\mathrm{TSM}\left(\mathrm{mg} \mathrm{L}^{-1}\right)$ & 0.56 & $<0.0001$ & 0.60 & $<0.0001$ & -0.64 & $<0.0001$ & -0.06 & NS \\
\hline $\operatorname{SRP}\left(\mu \mathrm{g} \mathrm{L}^{-1}\right)$ & 0.60 & $<0.0001$ & 0.52 & $<0.001$ & -0.62 & $<0.0001$ & -0.17 & NS \\
\hline $\mathrm{NO}_{3}\left(\mathrm{mg} \mathrm{L}^{-1}\right)$ & 0.43 & $<0.01$ & 0.82 & $<0.0001$ & -0.76 & $<0.0001$ & -0.15 & NS \\
\hline POC $\left(\mathrm{mg} \mathrm{L}^{-1}\right)$ & 0.61 & $<0.0001$ & 0.52 & $<0.0001$ & -0.65 & $<0.0001$ & -0.14 & NS \\
\hline $\mathrm{C}: \mathrm{N}$ & -0.45 & $<0.01$ & -0.54 & $<0.0001$ & 0.70 & $<0.0001$ & 0.17 & NS \\
\hline DOC/POC & -0.35 & $<0.05$ & -0.50 & $<0.001$ & 0.56 & $<0.0001$ & 0.02 & NS \\
\hline $\mathrm{DOC}\left(\mathrm{mg} \mathrm{L}^{-1}\right)$ & 0.61 & $<0.0001$ & 0.24 & ns & -0.47 & $<0.001$ & 0.15 & NS \\
\hline$a_{250}: a_{365}$ & 0.31 & $<0.05$ & 0.25 & ns & -0.49 & $<0.001$ & 0.34 & $<0.05$ \\
\hline FI & 0.55 & $<0.0001$ & 0.76 & $<0.0001$ & -0.75 & $<0.0001$ & -0.11 & $<0.05$ \\
\hline$\beta: \alpha$ & 0.53 & $<0.0001$ & 0.79 & $<0.0001$ & -0.82 & $<0.0001$ & -0.05 & NS \\
\hline$\% \mathrm{C} 1$ & -0.58 & $<0.0001$ & -0.72 & $<0.0001$ & 0.74 & $<0.0001$ & 0.07 & $<0.05$ \\
\hline$\% \mathrm{C} 2$ & -0.48 & $<0.0001$ & -0.61 & $<0.0001$ & 0.74 & $<0.0001$ & -0.12 & NS \\
\hline$\% \mathrm{C} 3$ & 0.53 & $<0.0001$ & 0.76 & $<0.0001$ & -0.70 & $<0.0001$ & -0.17 & $<0.05$ \\
\hline$\% \mathrm{C} 4$ & -0.47 & $<0.001$ & -0.59 & $<0.0001$ & 0.60 & $<0.0001$ & 0.06 & NS \\
\hline$\% \mathrm{C} 5$ & 0.55 & $<0.0001$ & 0.72 & $<0.0001$ & -0.73 & $<0.0001$ & -0.06 & $<0.01$ \\
\hline$\% \mathrm{C} 6$ & 0.55 & $<0.0001$ & 0.41 & $<0.01$ & -0.52 & $<0.001$ & 0.06 & NS \\
\hline$\% \mathrm{C} 7$ & 0.27 & NS & 0.27 & NS & -0.41 & $<0.01$ & 0.10 & NS \\
\hline
\end{tabular}

Relationships are based on averages values calculated at each sampling sites $(n=50)$. Correlations for each surveys are presented in the Supplementary Table 1

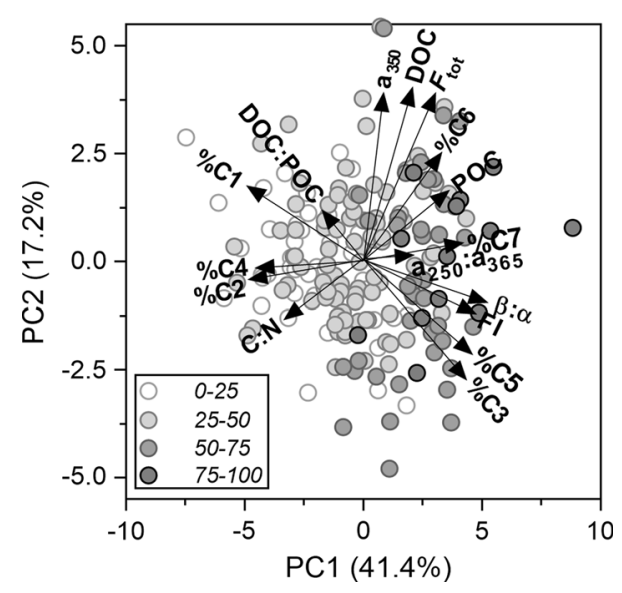

Fig. 3 Graphical representation of PCA results, including loadings plot for the input variables and scores plot for stations. Markers are colored according to a gradient of human disturbance that corresponds to the sum of $\%$ urban $+\%$ croplands
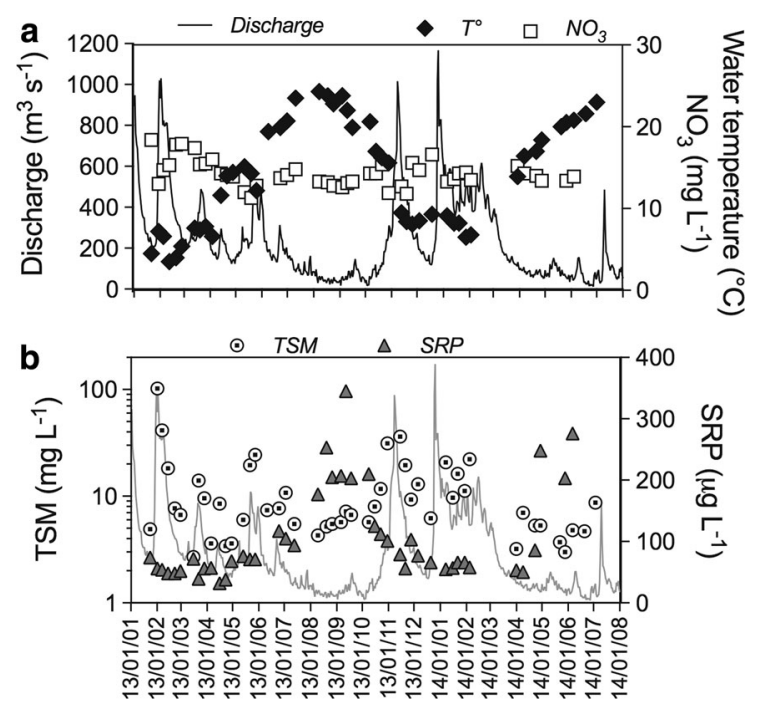

Fig. 4 Temporal variability of a stream discharge, water temperature and $\mathrm{NO}_{3}{ }^{-}$concentrations and b TSM and SRP concentrations in the Meuse River at the city of Liège 
between 4.3 and 9.3, showing gradual fluctuation from winter (lower values) to summer (higher values). More details on the relationships between TSM, nutrients,
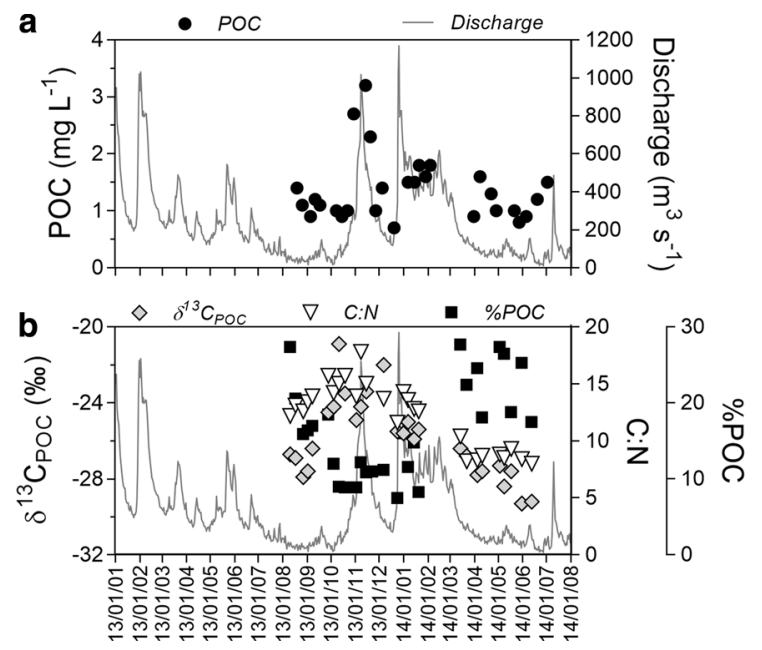

Fig. 5 Temporal variability of a POC concentrations and stream discharge and $\mathbf{b} \delta^{13} \mathrm{C}_{\mathrm{POC}}, \mathrm{C}: \mathrm{N}$ ratios and \%POC in the Meuse River at the city of Liège
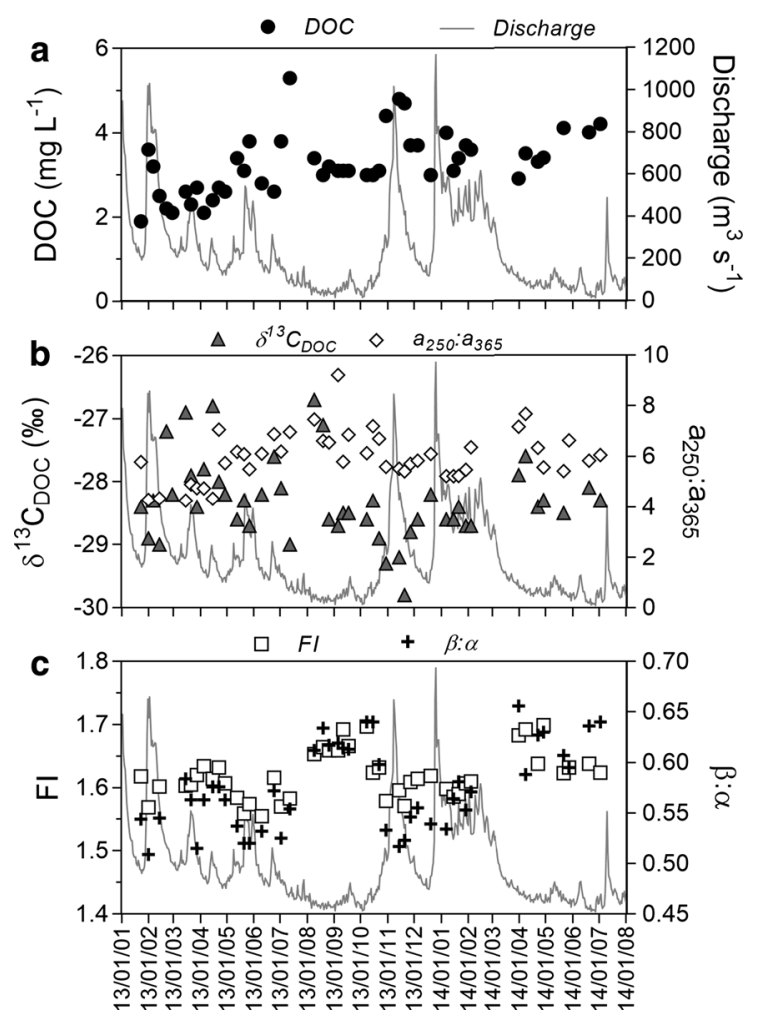

Fig. 6 Temporal variability of a DOC concentrations and stream discharge, $\mathbf{b} \delta^{13} \mathrm{C}_{\text {DOC }}$ and $\mathrm{a}_{250}: \mathrm{a}_{365}$ ratios and $\mathbf{c} \mathrm{FI}$ and $\beta: \alpha$ ratios in the Meuse River at the city of Liège fluvial POM and DOM and stream discharge are available in Supplementary Fig. 3.

Terrestrial humic-like components $\mathrm{C} 1, \mathrm{C} 2$ and $\mathrm{C} 4$ and microbial humic-like components $\mathrm{C} 3$ and $\mathrm{C} 5$ exhibited similar temporal variations in the Meuse River and therefore were grouped (summed) into two groups. $F_{\text {Max }}$ of these components were positively correlated with discharge (Fig. 7; Supplementary Fig. 4), but showed low variation during base flow period. Thus, $F_{\text {Max }}$ values remained stable around 0.3-0.35 R.U. between periods of heavy rainfall along the entire hydrological cycle despite large fluctuations in stream discharge. $F_{\text {Max }}$ of C6 were also found to peak with stream discharge, however the largest change recorded was the increase in fluorescence intensity during summer months leading to higher $F_{\text {Max }}$ of C6 during low flow periods compared to high flow periods. Consequently, no relationship was observed between $F_{\text {Max }}$ of C6 and stream discharge. Finally, C7 displayed little temporal variation but trended to decrease with increasing discharge (Supplementary Fig. 3). Among the different components, C6 was the only component to exhibit significant and positive relationships between its $F_{\text {Max }}$ values and SRP (Pearson $\mathrm{r}=0.46, \mathrm{p}<0.0001, \mathrm{n}=44$ ) and
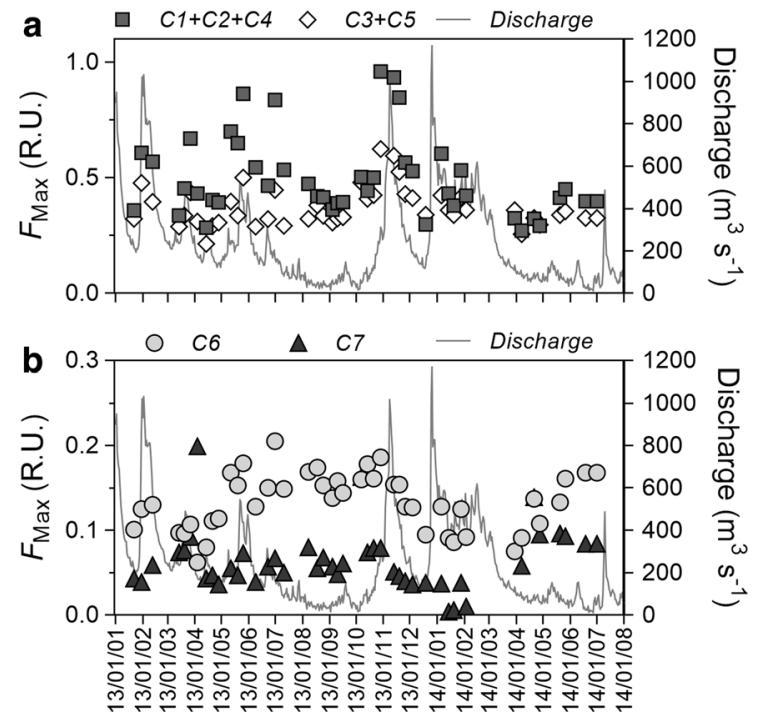

Fig. 7 Temporal variability of a $F_{\text {Max }}$ values of terrestrial humic-like components $(\mathrm{C} 1, \mathrm{C} 2, \mathrm{C} 4)$ and microbial humic-like components $(\mathrm{C} 3, \mathrm{C} 5)$ and $\mathbf{b} F_{\mathrm{Max}}$ values of anthropogenic microbial humic-like component $\mathrm{C} 6$ and protein-like component $\mathrm{C} 7$ in the Meuse River at the city of Liège 
water temperature (Pearson $\mathrm{r}=0.60, \mathrm{p}<0.0001$, $\mathrm{n}=44)$.

\section{Discussion}

It has already be shown that the conversion of natural land cover for human activities in the Walloon Region has led to drastic losses in soil stability and SOC content and a widespread eutrophication in surface waters (Bellayachi et al. 2014; Descy et al. 2009). In line with several studies carried out in a wide variety of catchments (Lu et al. 2014b; Masese et al. 2016; Parr et al. 2015; Wilson and Xenopoulos 2009) we found that human activities also strongly affect fluvial OM sources, which shifted toward a more microbial/ algal and less plant/soil-derived character as human disturbance increases. It is possible that other elements of the landscape such as soil types also affect fluvial OM (e.g., Autio et al. 2016). However, land use effects on fluvial OM trend to be more important than soil effects (Graeber et al. 2012; Butman et al. 2015), as suggested here by the fact that land cover factor (urban, croplands and forest areas) were stronger predictors than other landscape variables (e.g., texture, $\mathrm{C}_{\text {org }}$ content) regardless of the fluvial OM properties considered (data not shown). The strength of the relationships between land use and DOM/POM properties also demonstrate the dominant role of human activities in altering fluvial $\mathrm{OM}$ at the regional scale. Greater inputs of microbial/algal components in the DOM pool in human-impacted catchments were evidenced by highest FI and $\beta: \alpha$ ratios (McKnight et al. 2001; Williams et al. 2010) and by the higher contribution of C3, C5 and C6 components. C3 and C5 components have been previously found to occur in catchments under agricultural influence and are both associated with biological activity and transformation of terrestrial OM (Stedmon and Markager 2005; Williams et al. 2010, 2013; Yamashita et al. 2010) while C6 is referred as an anthropogenic pool of organic molecules generated in streams that trend to occur mainly in urbanized aquatic ecosystems (Hosen et al. 2014; Williams et al. 2016). The preferential occurrence of these components in agricultural or urban catchments is confirmed by our study as \% 3 and $\% \mathrm{C} 5$ were better correlated with croplands while \%C6 was better correlated with urban areas (Table 4). Greater contributions of microbial/algal components in the POM pool was evidenced by the negative relationship between $\mathrm{C}: \mathrm{N}$ ratio and urban areas and croplands given that the $\mathrm{C}: \mathrm{N}$ ratios of microbial and algal sources are typically lower (4-8) than those of terrestrial sources (terrestrial higher plants from 15 to $>50$, arable soils from 10 to 12) (Besemer et al. 2009; Finlay and Kendall 2007).

Impact of agricultural practices on the terrestrial sources of fluvial OM

Gradual loss of aromatic plant/soil-derived OM along a gradient of human disturbance-evidenced for example by the decreasing relative contribution of aromatic components $\mathrm{C} 1, \mathrm{C} 2$ and $\mathrm{C} 4-$ can result from several processes such as (1) disconnection from terrestrial sources in urban areas (Hosen et al. 2014), (2) difference in litter quality inputs between forest leaves and crop residues, and (3) greater photodegradation of aromatic molecules due to reduced canopy in urban and agricultural catchments (McEnroe et al. 2013). In parallel, an increase in microbial activity and/or algal primary production in human-impacted aquatic ecosystems due to higher nutrient content in waters and greater sunlight exposure as a result of reduced canopy is often invoked as the main processes leading to the enrichment in microbial/algal components (Masese et al. 2016; McEnroe et al. 2013; Williams et al. 2010; Wilson and Xenopoulos 2009; Yang et al. 2012). However, our results highlight that transformation of terrestrial sources of OM by agricultural practices can also contribute to the abovementioned pattern as previously suggested (Wilson \& Xenopoulos 2009; Williams et al. 2016).

The first line of evidence comes from the comparison of DOM composition between surface and ground waters. Groundwaters receive DOM from superficial sources trough the vertical percolation of soil waters and precipitation that hydrologically connect organicrich topsoil and the saturated zone of aquifers (Aravena et al. 2004; Shen et al. 2015). During its vertical transport DOM is subjected to interactions with soil minerals leading to the selective removal of more aromatic and hydrophobic molecules while soil microbial communities both consume and produce DOM (Hobara et al. 2014; Inamdar et al. 2012; Shen et al. 2015). Consequently, groundwaters commonly exhibit lower DOM content of lower aromaticity and with a greater microbial character compared to surface 
waters, as observed in our study (Fig. 2). The presence of C3 and C5 in groundwaters implies that these components were produced in soils, and their increasing relative contribution with croplands means that their production were greater in agricultural soils given that urban areas characterized by large impervious surfaces likely do not represent an important source of terrestrial $\mathrm{OM}$ for groundwaters. The positive correlation between stream discharge and $F_{\text {Max }}$ of $\mathrm{C} 3$ and C5 in the Meuse River provides another line of evidence that these components are from terrestrial origin. It should be noted that the presence of $\mathrm{C} 7$ in groundwaters suggests that this component is associated with breakdown products of lignin that fluoresce in this region of the EEM (Hernes et al. 2009) rather than with recent in-stream autochthonous production.

The negative relationship between $\mathrm{C}: \mathrm{N}$ ratio of POM and human land use also supports an effect of agricultural practices on terrestrial OM composition. In the 1990's, phytoplankton was identified as a major source of POM in the Meuse River, accounting for nearly $60 \%$ of the POC (Descy and Gosselain 1994). However planktonic productivity has drastically declined since the mid-2000s due to the expansion of Asian clams (Corbicula spp.), an invasive filter-feeder that consume phytoplankton biomass due to their filtration (Pigneur et al. 2014). The lack of relationship between Chl- $a$ concentrations and land use irrespective of the season while POC concentrations strongly correlated with urban areas and croplands (Table 4) supports the fact that phytoplankton is not a strong contributor to the POM pool nowadays. Thus, lower $\mathrm{C}: \mathrm{N}$ ratios can be mainly attributed to microbial inputs in the POM pool. In the lower Chesapeake Bay region, POM in urban and croplands headwater streams were found to have similar $\mathrm{C}: \mathrm{N}$ ratios significantly lower than those measured in forest headwater streams ( $\mathrm{Lu}$ et al. 2014b). In our case, POC concentrations similarly correlated with urban and croplands, indicating that both human land use types impact POM content. However, C:N ratios better correlated with croplands, suggesting that cultivated areas were a primary control on POM composition relative to urban areas. Although we cannot rule out a potential impact of greater in-stream microbial production, it is reasonable to assume that the impact of agricultural practices that lead to higher contribution of microbial components in the soil DOM pool also affect soil POM.

A higher microbial character in fluvial $\mathrm{OM}$ in agricultural catchments likely reflects greater SOM decomposition. Recent advances in soil science have shown that (1) SOM degradation is rather controlled by physical protection and accessibility of soil microorganisms to SOM rather than the chemical composition, or recalcitrance, of soil organic molecules (Dungait et al. 2012; Schmidt et al. 2011) and (2) that SOM decomposition leads to a progressive evolution of SOM chemistry toward a more microbial character due to the incorporation of microbial metabolites and microbially reworked plant-derived compounds in the residual SOM (Gleixner 2013; Hobara et al. 2014; Malik and Gleixner 2013). Several agricultural practices can potentially affect one of these two features or both. For example, tillage destroys soil aggregates and therefore may make available to microbial decomposers SOM previously localized in macro- and micro-aggregates of soils and physically protected from degradation (McLauchlan 2006; Six et al. 1998). Tillage and cultivation also reverse soil profiles and expose at the soil surface SOM from deeper soil horizons that become subjected to drastically different environmental conditions (e.g., exposure to wet-dry cycles, temperature, moisture and aeration) that can promote litter and SOM decomposition (Kalbitz et al. 2000). In parallel, application of organic fertilizers (manure) can serve as a stimulator by providing nutrients and organic matter easily degradable for soil organisms, leading to an increase in decomposition rate of SOM through the so-called "priming effect" (Blagodatskaya and Kuzyakov 2008; Chantigny 2003). Finally, soil liming has been shown to stimulate microbial activity through increasing soil pH (Kalbitz et al. 2000). By examining SOM composition along a gradient of land use from North to South America, Pisani et al. (2016) showed that the conversion of native to cultivated soil resulted in a decrease of plant-derived SOM components due to enhanced degradation of more recalcitrant SOM compounds such as lignin or cutin while microbial derived-organic matter accumulated. The strong similarity between the shift in SOM composition reported by this study and other in soils sciences (Quénéa et al. 2006) and those reported for fluvial OM in the Meuse basin provides a strong support to our hypothesis that the evolution of fluvial OM toward a more microbial and less 
plant/soil-derived character can be related to an effect of agricultural practices on terrestrial OM.

Our study falls in line with numerous observations from other regions showing that soil destabilization associated with intensive croplands affects fluvial OM. A recent compilation of DOC ages across 135 watersheds located worldwide revealed that increasing human disturbance led to older DOC in streams and rivers due to the destabilization of aged SOM (Butman et al. 2015). Although DOC age was not measured, exposure of older deeper SOM in croplands is likely to occur in the Walloon region and our data suggests that this results in a less aromatic OM pool with greater microbial inputs. While this pattern is consistent with laboratory studies comparing pore-water DOM in soils under different vegetation cover (e.g., Kalbitz et al. 2003), there is in the literature several examples reporting an opposite trend. For example, our results contrasts with a field study conducted in headwater catchments in Germany where agricultural practices led to the mobilization of more humified and aromatic DOM in streams compared to forest and wetland catchments (Graeber et al. 2012). Similarly, waterextractable DOM from agricultural soils in Canada was found to be more chemically complex compared to forest and grassland soils (Xu et al. 2013). In Australia, the reconversion of coastal wetlands for agricultural and urban purposes was without effects on stream DOM, the latter being characterized by a chemical composition typical of former wetland ecosystems (Petrone et al. 2011). On considering that mobilization of older DOM with increasing human disturbance is a globally consistent pattern (Evans et al. 2007; Sickman et al. 2010; Butman et al. 2015), the contrasting observations reported above suggest that the net effect on DOM chemical structure can vary widely across catchments due to the interplay of several processes. Indeed, OM cycling in soils is highly complex and depends on numerous parameters such as soil chemical and structural properties, soil fauna, environmental conditions (climate, hydrology) or vegetation cover, and similar management practices can have contrasting effects on OM depending on local conditions as several of soil properties are modified at the same time (Chantigny 2003; Ogle et al. 2005). In addition to soil/SOM properties and agricultural practices, land use history, native vegetation and timing of SOM stabilization after land reconversion are additional drivers that will contribute to determine stream DOM composition in agricultural landscapes (Sickman et al. 2010; Petrone et al. 2011; Yamashita et al. 2011).

Seasonal fluctuation in fluvial OM and the impact of human activities

The seasonal variability in stream DOC concentrations contrasts with the more common pattern reported in other temperate streams whereby stream DOC typically increases with stream discharge, resulting in higher concentrations during high flow periods compared to low flow periods (Lambert et al. 2014; Raymond and Saiers 2010; Sanderman et al. 2009). In the Meuse River, increases in DOC concentrations at peak discharge are consistent with greater inputs of terrestrial DOM during rainfall events (Lambert et al. 2014; Sanderman et al. 2009) but stable levels of $F_{\text {Max }}$ of terrestrial humic- and microbial-like components along the entire hydrological cycle means that terrestrial inputs are relatively constant and hydrologically independent in-between rainfall episodes. A similar pattern was observed at the scale of the Meuse basin whereby $F_{\mathrm{Max}}$ of terrestrial components were slightly higher during S2 (summer period, low specific discharge) relative to $\mathrm{S} 1$ (winter period, high specific discharge). This likely reflects modification and/or reorganization of hydrological flow paths that connect terrestrial soils to aquatic ecosystems by agricultural practices and urbanization engineering (Kaushal and Belt 2012; Stanley et al. 2012).

In parallel, increasing FI and $\beta: \alpha$ ratios in the Meuse River during summer indicate greater inputs of fresh and microbially-derived compounds (Williams et al. 2010; Wilson and Xenopoulos 2009) that coincided with rising fluorescence of C6 (Fig. 7). C6 is associated with the biological production of DOM within aquatic ecosystems and is generally described as being of anthropogenic origin because it seems to be identified primarily in urban catchments (Hosen et al. 2014; Parr et al. 2015; Williams et al. 2016). The absence of C6 in groundwaters (Fig. 2) and its dynamic in the Meuse basin characterized by increasing $F_{\text {Max }}$ values in summer (Fig. 7; Table 3 ) related to increasing water temperature (Fig. 4; Table 1) support an autochthonous origin. At the spatial scale, \%C6 correlated better with urban areas than croplands, supporting the statement according to which that urbanization leads to a stream DOM composition 
distinct from those observed in natural and agricultural catchments. To explore further the link between urban areas and DOM quality, we calculated the human population in the study catchments from available datasets from the European Environment Agency (https://www.eea.europa.eu/) and found that population density was the best predictor for the occurrence of C6 in watercourse of the Meuse basin (Fig. 8). This link between $\mathrm{C} 6$ and human population-also recently reported in freshwater ecosystems of the Great Lakes region (Williams et al. 2016) — highlights the fact that populated areas have a strong influence on DOM quality in the surrounding aquatic ecosystems.

The reason for a preferential occurrence of C6 in urban areas remains unclear. One possible explanation is increased primary production in SRP-rich waters in urban catchments (Williams et al. 2016), potentially linked to an algal origin (McEnroe et al. 2013; Williams et al. 2013). While a link with SRP seems reasonable, we can rule out an algal origin because (1) seston Chl- $a$ concentrations were not impacted by land cover, and (2) algae benthic production is limited in large systems due to limited light penetration and management of river beds for navigation (dredging, artificial banks) that limits the place for algae growth (Descy et al. 2009). Another sources could be inputs from wastewaters and/or septic systems as $20 \%$ of domestic wastewater is delivered untreated directly into streams and rivers in the Walloon region. However, this source cannot explain the seasonal pattern observed in the Meuse River because only $1 \%$ of wastewaters in large agglomerations such as Liège are not collected (Bellayachi et al. 2014). Moreover, the seasonal pattern of SRP concentrations in watercourse of the Walloon region is similar to those reported in lowland rivers of Flanders (northern Belgium), where higher SRP concentrations in summer are related to the mobilization of $\mathrm{P}$ from

Fig. 8 Relationships between \%C6 and a croplands, b urban areas, and $\mathbf{c}$ population density
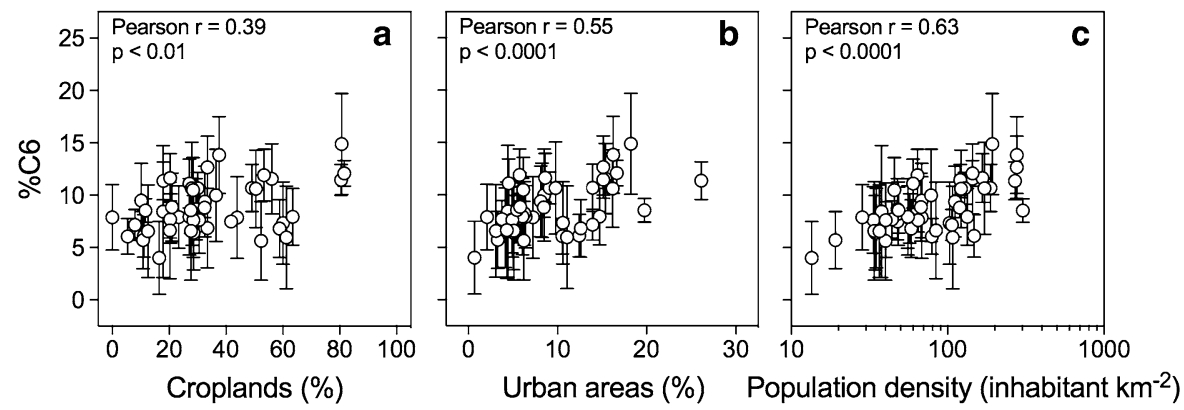

sediments to the water column rather than point source effluent inputs (Smolders et al. 2017). The positive correlations between C6, temperature and SRP and the fact that $F_{\text {Max }}$ values of C6 increase at peak discharge rather suggest an origin from heterotrophic microbial activity that use terrestrial DOM as a substrate.

For POC, increasing concentrations with increasing discharge observed both in the Meuse River and across the basin advocate for the dominance of terrestrial sources. However, there was a strong co-variation between $\delta^{13} \mathrm{C}_{\mathrm{POC}}$ and $\mathrm{C}: \mathrm{N}$ ratios (Fig. 5), suggesting that different sources contribute to fluvial POM. High $\%$ POC and $\mathrm{C}: \mathrm{N}$ ratios $<10$ during the low turbidity period in spring and early summer 2014 strongly suggest an autochthonous contribution from freshwater autotrophs such as plankton or macrophytes (Finlay and Kendall 2007), an hypothesis supported by low $\delta^{13} \mathrm{C}_{\text {POC }}$ values $(<30 \%)$ in some tributaries of the Meuse River during field surveys. Given the recent evolution of pelagic planktonic dynamics in the Meuse River (Pigneur et al. 2014), the most likely source is development of macrophytes and/or benthic algae. During the field survey carried out in summer (S2), similar low $\mathrm{C}: \mathrm{N}$ ratio and $\delta^{13} \mathrm{C}_{\mathrm{POC}}$ values were recorded, suggesting that this autochthonous contribution occurs across the whole basin. However, and contrary to the autochthonous production of DOM, autochthonous POM appears not to be impacted by land use as no correlation between $\mathrm{C}: \mathrm{N}$ ratio and any type of land use was observed during this period (Supplementary Table 1).

\section{Fluvial DOM versus fluvial POM}

Our study points both to similarities and differences regarding the impact of human activities on fluvial pools of DOM and POM. Thus, agricultural practices 
may promote SOM degradation and subsequent inputs of microbial material in terrestrial DOM and POM pools, contributing to the greater microbial character of fluvial $\mathrm{OM}$ in agricultural catchments once exported to the fluvial network. Decreasing DOC:POC ratios with increasing cropland extent implies that the transfer of terrestrial POM is proportionally greater than the transfer of terrestrial DOM in these areas. This likely reflects the ongoing high soil erosion due to rainfall and water runoff occurring in the Walloon Region (Bellayachi et al. 2014), a process consistent with the higher load of TSM measured in agricultural catchments (Table 4). In parallel, autochthonous sources of fluvial OM differed in terms of origin, dynamics, and controlling drivers. Hence, autochthonous DOM likely originated from heterotrophic bacterial activity while the most plausible source of autochthonous POM was aquatic plants. Then, despite being systematically lower relative to terrestrial DOM inputs, in-stream bacterial production of DOM seems to occur along the entire hydrological cycle with a peak in summer (e.g., Fig. 7) whereas autochthonous POM contributed significantly to fluvial OM only in summer. A dominance of aquatic sources relative to terrestrial inputs into fluvial POM in summer was furthermore supported by the fact that DOC:POC ratios were not correlated with croplands during S2 (Table 4). Finally, while the generation of autochthonous DOM was markedly greater in urban environments, anthropogenic activities did not influence the autochthonous production of POM.

There was no correlation between the $\delta^{13} \mathrm{C}$ signatures of DOC and POC both during field surveys and

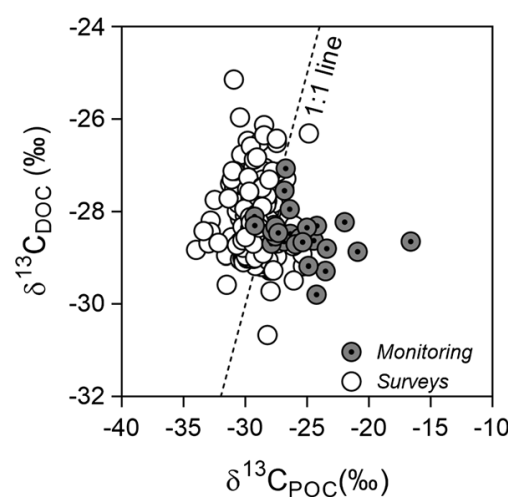

Fig. 9 Comparison of the $\delta^{13} \mathrm{C}$ signatures of DOC versus $\delta^{13} \mathrm{C}$ signatures of $\mathrm{POC}$ for samples collected during surveys and the monitoring the monitoring (Fig. 9). At least two explanations can be invoked to explain this result. First, a different origin and nature of DOC and POC, especially during the summer period during which fluvial POM is dominated by autochthonous sources depleted in ${ }^{13} \mathrm{C}$ while fluvial DOM remains dominated by terrestrial inputs. Secondly, differences in the hydrological mechanisms that control the export of terrestrial DOC and POC. Indeed, detailed investigations have shown that terrestrial DOC export is the result of a hydrological flushing of potentially soluble $\mathrm{OM}$ accumulated in soil surface horizons while terrestrial POC export is rather controlled by an erosion process that requires more threshold energy to initiate soil erosion and destabilization of stream banks (Dhillon and Inamdar 2014; Jeong et al. 2012). Differences in the hydrological transfer processes of DOC and POC were evidenced by the contrasting patterns observed for $\delta^{13} \mathrm{C}_{\mathrm{DOC}}$ and $\delta^{13} \mathrm{C}_{\mathrm{POC}}$ in the Meuse River. Variability in $\delta^{13} \mathrm{C}_{\mathrm{DOC}}$ was marked by significant (up to $2 \%$ ) short-term fluctuations no related to changes in stream discharge while changes in $\delta^{13} \mathrm{C}_{\mathrm{POC}}$ were more seasonal and related to stream discharge fluctuations (Figs. 5, 6; Supplementary Fig. 2). This suggests that impacts of urban engineering and agricultural practices on the hydrological transfer of terrestrial sources are likely different and specific to DOM and POM. Finally, the lack of relationship between the $\delta^{13} \mathrm{C}$ signatures of DOC and POC suggests limited physical exchanges between fluvial DOM and POM pools.

\section{Conclusion}

The controls on fluvial OM can be summarized as a function of terrestrial production of OM, hydrological transfer from the terrestrial to the aquatic ecosystems, and in-stream production and processing. All these fundamental aspects can potentially be impacted by human activities (Stanley et al. 2012). In this study, we showed that human activities in the Walloon region have affected both terrestrial and aquatic sources of fluvial OM, leading to a shift in composition toward a more microbial/algal and less plant/soil-derived character in streams and rivers. Our results also showed that different aspects of human activities (e.g., population associated with urban areas and croplands) have specific impact on OM in aquatic ecosystems. Overall, 
we showed that impacts from human activities on the dynamics of fluvial DOM and POM are complex as they can be similar (e.g., impact on terrestrial sources), specific (e.g., hydrological transfer, impact on autochthonous sources), seasonally independent (e.g., for fluvial DOM) or seasonally dependent (e.g., for fluvial POM). In-stream processing of fluvial OM was not investigated in our study, but it is likely that DOM and POM cycling differ along a gradient of human disturbance, as previously demonstrated in other environments (Petrone et al. 2011; Williams et al. 2010). This indirectly confirmed by a parallel study based on the same samplings showing that $\mathrm{CO}_{2}$ and $\mathrm{CH}_{4}$ increased and $\mathrm{O}_{2}$ decreased in streams with increasing fraction of agricultural land cover on the catchment, strongly suggesting enhanced OM degradation in these streams (Borges et al. 2018).

\begin{abstract}
Acknowledgements We thank Christiane Lancelot (Université Libre de Bruxelles) for access to the Perkin-Elmer UV/Vis 650S, Aurore Beulen, Coline Schartz, Sandro Petrovic, Jean Tseng, Anna Jurado and Marc-Vincent Commarieu (University of Liège) for analytical and fieldwork support, the DGO2 Direction générale opérationnelle de la Mobilité et des Voies hydrauliques of the Service public de Wallonie for providing freshwater discharge data. Alberto V. Borges is a senior research associate at the Fonds National de la Recherche Scientifique (FNRS). This is a contribution to the WAL-H2OGHG project funded by the Walloon Institute of Sustainable Development (FNRS Project No. X.3007.17). The authors declare no conflict of interest. We thank the two anonymous reviewers for constructive and stimulating comments on the previous version of the manuscript.
\end{abstract}

Open Access This article is distributed under the terms of the Creative Commons Attribution 4.0 International License (http:// creativecommons.org/licenses/by/4.0/), which permits unrestricted use, distribution, and reproduction in any medium, provided you give appropriate credit to the original author(s) and the source, provide a link to the Creative Commons license, and indicate if changes were made.

\section{References}

Accoe F, Boeckx P, Van Cleemput O, Hofman G, Hui X, Bin H, Guanxiong C (2002) Characterization of soil organic matter fractions from grassland and cultivated soils via $\mathrm{C}$ content and $\delta^{13} \mathrm{C}$ signature. Rapid Commun Mass Spectrom 16(23):2157-2164

Aitkenhead-Peterson J, McDowell W, Neff J, Stuart E, Robert L (2003) Sources, production, and regulation of allochthonous dissolved organic matter inputs to surface waters. In: Findlay EG, Sinsabaugh RI (eds) Aquatic ecosystems: interactivity of dissolved organic matter. Academic press, New York, pp 26-70

APHA (1998) Standard methods for the examination of water and wasteater. American Public Health Association, Washington, DC

Aravena R, Wassenaar LI, Spiker EC (2004) Chemical and carbon isotopic composition of dissolved organic carbon in a regional confined methanogenic aquifer. Isot Environ Health Stud 40(2):103-114

Autio I, Soinne H, Helin J, Asmala E, Hoikkala L (2016) Effect of catchment land use and soil type on the concentration, quality, and bacterial degradation of riverine dissolved organic matter. Ambio 45(3):331-349

Ballabio C, Panagos P, Monatanarella L (2016) Mapping topsoil physical properties at European scale using the LUCAS database. Geoderma 261:110-123

Battin TJ, Luyssaert S, Kaplan LA, Aufdenkampe AK, Richter A, Tranvik LJ (2009) The boundless carbon cycle. Nat Geosci 2(9):598

Bellayachi A, Brahy V, Cuvelier C, Dejemeppe J, Genereux C, Maes E, Marzo G, Renard V, Thiry V (2014) Environmental outlook for Wallonia. SPW Editions, Namur

Besemer K, Luef B, Preiner S, Eichberger B, Agis M, Peduzzi P (2009) Sources and composition of organic matter for bacterial growth in a large European river floodplain system (Danube, Austria). Org Geochem 40:321-331

Blagodatskaya E, Kuzyakov Y (2008) Mechanisms of real and apparent priming effects and their dependence on soil microbial biomass and community structure: critical review. Biol Fertil Soils 45(2):115-131

Boëchat I, Krüger A, Chaves R, Graeber D, Gücker B (2014) Land-use impacts on fatty acid profiles of suspended particulate organic matter along a larger tropical river. Sci Total Environ 482:62-70

Borcard D, Gillet F, Legendre P (2011) Numerical ecology with R. Springer, New York

Borges AV, Darchambeau F, Lambert T, Bouillon S, Morana C, Brouyère S, Hakoun V, Jurado A, Tseng H-C, Descy J-P, Roland FAE (2018) Effects of agricultural land use on fluvial carbon dioxide, methane and nitrous oxide concentrations in a large European river, the Meuse (Belgium). Sci Total Environ 610-611:342-355

Burny P, Debode F (2013) Is organic farming the solution for the future of Walloon agriculture? In: The sixth international scientific conference" rural development 2013". Proceedings, vol. 6, book 1. ASU Publishing Center, pp 514-517

Butman DE, Wilson HF, Barnes RT, Xenopoulos MA, Raymond PA (2015) Increased mobilization of aged carbon to rivers by human disturbance. Nat Geosci 8:112-116

Carpenter SR, Stanley EH, Vander Zanden MJ (2011) State of the world's freshwater ecosystems: physical, chemical, and biological changes. Annu Rev Environ Resour 36:75-99

Chantigny MH (2003) Dissolved and water-extractable organic matter in soils: a review on the influence of land use and management practices. Geoderma 113(3):357-380

Cronan C, Piampiano J, Patterson H (1999) Influence of land use and hydrology on exports of carbon and nitrogen in a Maine river basin. J Environ Qual 28(3):953-961

de Brogniez D, Ballabio C, Stevens A, Jones RJA, Montanarella L, van Wesemael B (2015) A map of the topsoil organic 
carbon content of Europe generated by a generalized additive model. Eur J Soil Sci 66:121-134

Delprat L, Chassin P, Lineres M, Jambert C (1997) Characterization of dissolved organic carbon in cleared forest soils converted to maize cultivation. Dev Crop Sci 25:257-266

Descy J-P, Gosselain V (1994) Development and ecological importance of phytoplankton in a large lowland river (River Meuse, Belgium). Phytoplankton in turbid environments: rivers and shallow lakes. Springer, New York, pp 139-155

Descy JP, Hardy MA, Sténuite S, Pirlot S, Leporcq B, Kimirei I, Sekadende B, Mwaitega SR, Sinyenza D (2005) Phytoplankton pigments and community composition in Lake Tanganyika. Freshw Biol 50:668-684

Descy J-P, Patrick K, Everbecq E, Verniers G, Usseglio-Polatera P, Gérard P, Viroux L, Beisel J-N, Smitz J (2009) Continental atlantic rivers. Rivers of Europe. Academic Press, London, pp 151-198

Dhillon GS, Inamdar S (2014) Storm event patterns of particulate organic carbon (POC) for large storms and differences with dissolved organic carbon (DOC). Biogeochemistry 118(1-3):61-81

Duan S, Amon RM, Brinkmeyer RL (2014) Tracing sources of organic matter in adjacent urban streams having different degrees of channel modification. Sci Total Environ 485:252-262

Dungait JA, Hopkins DW, Gregory AS, Whitmore AP (2012) Soil organic matter turnover is governed by accessibility not recalcitrance. Glob Change Biol 18(6):1781-1796

EEA (2014) European environmental agency, corine land cover 2006 raster data. http://www.eea.europa.eu/data-andmaps/data/corine-land-cover-2006-raster-3. Accessed June 2015

Evans CD, Freeman C, Cork LG, Thomas DN, Reynolds B, Billet MF, Garnett MH, Norris D (2007) Evidence against recent climate-induced destabilisation of soil carbon from $14 \mathrm{C}$ analysis of riverine dissolved organic matter. Geophys Res Lett 34:L07407

Finlay JC, Kendall C (2007) Stable isotope tracing of temporal and spatial variability in organic matter sources to freshwater ecosystems. Stable Isot Ecol Environ Sci 2:283-333

Genot V, Colinet G, Brahy V, Bock L (2009) L'état de la fertilité des terres agricoles et forestières en région wallonne. Biotechnol Agron Soc Envrion 13(1):121-138

Giling DP, Grace MR, Thomson JR, Mac Nally R, Thompson RM (2014) Effect of native vegetation loss on stream ecosystem processes: dissolved organic matter composition and export in agricultural landscapes. Ecosystems 17(1):82-95

Gleixner G (2013) Soil organic matter dynamics: a biological perspective derived from the use of compound-specific isotopes studies. Ecol Res 28(5):683-695

Graeber D, Gelbrecht J, Pusch MT, Anlanger C, von Schiller D (2012) Agriculture has changed the amount and composition of dissolved organic matter in Central European headwater streams. Sci Total Environ 438:435-446

Hernes PJ, Bergamaschi BA, Eckard RS, Spencer RG (2009) Fluorescence-based proxies for lignin in freshwater dissolved organic matter. J Geophys Res. doi:10.1029/ 2009JG000938
Hobara S, Osono T, Hirose D, Noro K, Hirota M, Benner R (2014) The roles of microorganisms in litter decomposition and soil formation. Biogeochemistry 118(1-3):471-486

Hosen JD, McDonough OT, Febria CM, Palmer MA (2014) Dissolved organic matter quality and bioavailability changes across an urbanization gradient in headwater streams. Environ Sci Technol 48(14):7817-7824

Inamdar S, Finger N, Singh S, Mitchell M, Levia D, Bais H, Scott D, McHale P (2012) Dissolved organic matter (DOM) concentration and quality in a forested mid-Atlantic watershed, USA. Biogeochemistry 108(1-3):55-76

Jeong JJ, Bartsch S, Fleckenstein JH, Matzner E, Tenhunen JD, Lee SD, Park SK, Park JH (2012) Differential storm responses of dissolved and particulate organic carbon in a mountainous headwater stream, investigated by high-frequency, in situ optical measurements. J Geophys Res. doi:10.1029/2012JG001999

Kaiser K, Kalbitz K (2012) Cycling downwards-dissolved organic matter in soils. Soil Biol Biochem 52:29-32

Kalbitz K, Solinger S, Park J-H, Michalzik B, Matzner E (2000) Controls on the dynamics of dissolved organic matter in soils: a review. Soil Sci 165(4):277-304

Kalbitz K, Schmerwitz J, Schwesig D, Matzner E (2003) Biodegradation of soil-derived dissolved organic matter as related to its properties. Geoderma 113(3):273-291

Kaushal SS, Belt KT (2012) The urban watershed continuum: evolving spatial and temporal dimensions. Urban Ecosyst 15(2):409-435

Lambert T, Pierson-Wickmann A-C, Gruau G, Jaffrézic A, Petitjean P, Thibault J-N, Jeanneau L (2014) DOC sources and DOC transport pathways in a small headwater catchment as revealed by carbon isotope fluctuation during storm events. Biogeosciences 11:3043-3056

Le Meur M, Mansuy-Huault L, Lorgeoux C, Bauer A, Gley R, Vantelon D, Montargès-Pelletier E (2017) Spatial and temporal variations of particulate organic matter from Moselle River and tributaries: a multimolecular investigation. Org Geochem 110:45-56

Lu YH, Bauer JE, Canuel EA, Chambers R, Yamashita Y, Jaffé R, Barrett A (2014a) Effects of land use on sources and ages of inorganic and organic carbon in temperate headwater streams. Biogeochemistry 119(1-3):275-292

Lu YH, Canuel EA, Bauer JE, Chambers R (2014b) Effects of watershed land use on sources and nutritional value of particulate organic matter in temperate headwater streams. Aquat Sci 76(3):419-436

Luo Z, Wang E, Sun OJ (2010) Soil carbon change and its responses to agricultural practices in Australian agroecosystems: a review and synthesis. Geoderma 155(3):211-223

Malik A, Gleixner G (2013) Importance of microbial soil organic matter processing in dissolved organic carbon production. FEMS Microbiol Ecol 86(1):139-148

Masese FO, Salcedo-Borda JS, Gettel GM, Irvine K, McClain ME (2016) Influence of catchment land use and seasonality on dissolved organic matter composition and ecosystem metabolism in headwater streams of a Kenyan river. Biogeochemistry 132:1-22

McEnroe NA, Williams CJ, Xenopoulos MA, Porcal P, Frost PC (2013) Distinct optical chemistry of dissolved organic matter in urban pond ecosystems. PLoS ONE 8(11):e80334 
McKnight DM, Boyer EW, Westerhoff PK, Doran PT, Kulbe T, Andersen DT (2001) Spectrofluorimetric characterization of dissolved organic matter for indication of precursor organic material and aromaticity. Limnol Oceanogr 46(1):38-48

McLauchlan K (2006) The nature and longevity of agricultural impacts on soil carbon and nutrients: a review. Ecosystems 9(8):1364-1382

Miltner A, Bombach P, Schmidt-Brücken B, Kästner M (2012) SOM genesis: microbial biomass as a significant source. Biogeochemistry 111(1-3):41-55

Murphy KR, Stedmon CA, Graeber D, Bro R (2013) Fluorescence spectroscopy and multi-way techniques. PARAFAC. Anal Methods 5(23):6557-6566

Nelson P, Baldock J, Oades J (1992) Concentration and composition of dissolved organic carbon in streams in relation to catchment soil properties. Biogeochemistry 19(1):27-50

Ngugi CC, Oyoo-Okoth E, Gichuki J, Gatune C, MwangiKinyanjui J (2016) Fingerprints of upstream catchment land use in suspended particulate organic matter (SPOM) at the river discharge sites in Lake Victoria (Kenya): insights from element, stable isotope and lipid biomarker analysis. Aquat Sci 79:1-15

Ogle SM, Breidt FJ, Paustian K (2005) Agricultural management impacts on soil organic carbon storage under moist and dry climatic conditions of temperate and tropical regions. Biogeochemistry 72(1):87-121

Ohno T (2002) Fluorescence inner-filtering correction for determining the humification index of dissolved organic matter. Environ Sci Technol 36(4):742-746

Parlanti E, Wörz K, Geoffroy L, Lamotte M (2000) Dissolved organic matter fluorescence spectroscopy as a tool to estimate biological activity in a coastal zone submitted to anthropogenic inputs. Org Geochem 31(12):1765-1781

Parr TB, Cronan CS, Ohno T, Findlay SE, Smith S, Simon KS (2015) Urbanization changes the composition and bioavailability of dissolved organic matter in headwater streams. Limnol Oceanogr 60(3):885-900

Petrone KC, Fellman JB, Hood E, Donn MJ, Grierson PF (2011) The origin and function of dissolved organic matter in agro-urban coastal streams. J Geophys Res. doi:10.1029/ 2010JG001537

Peuravuori J, Pihlaja K (1997) Molecular size distribution and spectroscopic properties of aquatic humic substances. Anal Chim Acta 337(2):133-149

Pigneur LM, Falisse E, Roland K, Everbecq E, Deliège JF, Smitz JS, Doninck K, Descy JP (2014) Impact of invasive Asian clams, Corbicula spp., on a large river ecosystem. Freshw Biol 59(3):573-583

Pisani O, Haddix ML, Conant RT, Paul EA, Simpson MJ (2016) Molecular composition of soil organic matter with land-use change along a bi-continental mean annual temperature gradient. Sci Total Environ 573:470-480

Quénéa K, Largeau C, Derenne S, Spaccini R, Bardoux G, Mariotti A (2006) Molecular and isotopic study of lipids in particle size fractions of a sandy cultivated soil (Cestas cultivation sequence, southwest France): sources, degradation, and comparison with Cestas forest soil. Org Geochem 37(1):20-44
Raymond PA, Saiers JE (2010) Event controlled DOC export from forested watersheds. Biogeochemistry 100(1-3):197-209

Reche I, Pace M, Cole J (1998) Interactions of photobleaching and inorganic nutrients in determining bacterial growth on colored dissolved organic carbon. Microb Ecol 36(3-4):270-280

Rosemond AD, Benstead JP, Bumpers PM, Gulis V, Kominoski JS, Manning DW, Suberkropp K, Wallace JB (2015) Experimental nutrient additions accelerate terrestrial carbon loss from stream ecosystems. Science 347(6226):1142-1145

Sanderman J, Lohse KA, Baldock JA, Amundson R (2009) Linking soils and streams: sources and chemistry of dissolved organic matter in a small coastal watershed. Water Resour Res. doi:10.1029/2008WR006977

Schmidt MW, Torn MS, Abiven S, Dittmar T, Guggenberger G, Janssens IA, Kleber M, Kögel-Knabner I, Lehmann J, Manning DA (2011) Persistence of soil organic matter as an ecosystem property. Nature 478(7367):49

Shen Y, Chapelle FH, Strom EW, Benner R (2015) Origins and bioavailability of dissolved organic matter in groundwater. Biogeochemistry 122(1):61-78

Sickman JO, DiGiorgio CL, Davisson ML, Lucero DM, Bergamaschi B (2010) Identifying sources of dissolved organic carbon in agriculturally dominated rivers using radiocarbon age dating: Sacramento-San Joaquin River Basin, California. Biogeochemistry 99:79-96

Six J, Elliott E, Paustian K, Doran J (1998) Aggregation and soil organic matter accumulation in cultivated and native grassland soils. Soil Sci Soc Am J 62(5):1367-1377

Smolders E, Baetens E, Verbeeck M, Nawara S, Diels J, Verdievel M, Peeters B, De Cooman W, Baken S (2017) Internal loading and redox cycling of sediment iron explain reactive phosphorus concentrations in lowland rivers. Environ Sci Technol 51:2584-2592

Stanley EH, Powers SM, Lottig NR, Buffam I, Crawford JT (2012) Contemporary changes in dissolved organic carbon (DOC) in human-dominated rivers: is there a role for DOC management? Freshw Biol 57(s1):26-42

Stedmon CA, Markager S (2005) Resolving the variability in dissolved organic matter fluorescence in a temperate estuary and its catchment using PARAFAC analysis. Limnol Oceanogr 50(2):686-697

Strauss EA, Lamberti GA (2002) Effect of dissolved organic carbon quality on microbial decomposition and nitrification rates in stream sediments. Freshw Biol 47(1):65-74

Tank JL, Rosi-Marshall EJ, Griffiths NA, Entrekin SA, Stephen ML (2010) A review of allochthonous organic matter dynamics and metabolism in streams. J N Am Benthol Soc 29(1):118-146

Tranvik LJ, Bertilsson S (2001) Contrasting effects of solar UV radiation on dissolved organic sources for bacterial growth. Ecol Lett 4(5):458-463

Tu M, Hall MJ, de Laat PJM, de Wit MJM (2005) Extreme floods in the Meuse River over the past century: aggraved by land-use changes? Phys Chem Earth 30:267-276

Williams CJ, Yamashita Y, Wilson HF, Jaffé R, Xenopoulos MA (2010) Unraveling the role of land use and microbial activity in shaping dissolved organic matter characteristics in stream ecosystems. Limnol Oceanogr 55(3):1159 
Williams CJ, Frost PC, Xenopoulos MA (2013) Beyond best management practices: pelagic biogeochemical dynamics in urban stormwater ponds. Ecol Appl 23(6):1384-1395

Williams CJ, Frost PC, Morales-Williams AM, Larson JH, Richardson WB, Chiandet AS, Xenopoulos MA (2016) Human activities cause distinct dissolved organic matter composition across freshwater ecosystems. Glob Change Biol 22(2):613-626

Wilson HF, Xenopoulos MA (2009) Effects of agricultural land use on the composition of fluvial dissolved organic matter. Nat Geosci 2(1):37

Xu N, Wilson H, Saiers JE, Entz M (2013) Eff ects of crop rotation and management system on water-extractable organic matter concentration, structure, and bioavailability in a chernozemic agricultural Soil. J Environ Qual 42:179-190

Yamashita Y, Scinto LJ, Maie N, Jaffé R (2010) Dissolved organic matter characteristics across a subtropical wetland's landscape: application of optical properties in the assessment of environmental dynamics. Ecosystems 13(7):1006-1019

Yamashita Y, Kloeppel BD, Knoepp J, Zausen GL, Jaffé R (2011) Effects of watershed history on dissolved organic matter characteristics in headwater streams. Ecosystems 14:1110-1122

Yang L, Hong H, Guo W, Huang J, Li Q, Yu X (2012) Effects of changing land use on dissolved organic matter in a subtropical river watershed, southeast China. Reg Environ Change 12(1):145-151

Zepp RG, Sheldon WM, Moran MA (2004) Dissolved organic fluorophores in southeastern US coastal waters: correction method for eliminating Rayleigh and Raman scattering peaks in excitation-emission matrices. Mar Chem 89(1):15-36 